\title{
Effect of Phase Change Materials on the performance of direct vapor generation solar organic Rankine cycle system
}

\author{
Jahan Zeb Alvi 1a, Yongqiang Fenga*, Qian Wanga**, Muhammad Imran ${ }^{\text {b }}$, Gang Peic \\ aSchool of Energy and Power Engineering, Jiangsu University, 301 Xuefu Road, Zhenjiang, China \\ ${ }^{b}$ School of Engineering and Applied Science, Aston University, Aston Triangle, B4 7ET, Birmingham, UK \\ 'Department of Thermal Science and Energy Engineering, University of Science and Technology of China, China \\ *Corresponding author: \\ Prof. Yongqiang Feng \\ hitfengyq@gmail.com \\ Prof. Qian Wang \\ qwang@ujs.edu.cn
}

\begin{abstract}
Phase change materials used for the storage of thermal energy can play a critical role in the efficient use and conservation of solar energy. The effect of the different types of phase change materials on the thermodynamic performance of a direct vapor generation solar organic Rankine cycle system is evaluated in this study. The system consists of an array of evacuated flat plate collectors, phase change material based thermal storage, expander, condenser, and organic fluid pump. The thermodynamic cycle model of the ORC system is integrated with phase change material heat storage tank that is modeled using the finite difference method in MATLAB. The thermodynamic performance of the system is analyzed by using 12 different phase change materials. Effect of phase change materials on the thermodynamic performance of organic Rankine cycle including the net power output, rise and fall in the working fluid temperature, and on the amount of energy stored and released are evaluated and compared for charging and discharging mode. The results indicate that $\mathrm{MgCl}_{2} \cdot 6 \mathrm{H}_{2} \mathrm{O}$ has shown the highest overall system's efficiency. However, $\mathrm{KNO}_{2}-\mathrm{NaNO}_{3}$ and Acetamide have resulted in maximum ORC and collector efficiency, respectively. Moreover, Acetamide, $\mathrm{KNO}_{2}-\mathrm{NaNO}_{3}$ and $\mathrm{Mg}\left(\mathrm{NO}_{3}\right)_{2} \cdot 6 \mathrm{H}_{2} \mathrm{O}$ have shown maximum rise and fall in organic fluid temperature, maximum net power and maximum amount of energy stored and released during charging and discharging mode. Salt hydrates have shown overall better performance among the selected PCMs in terms of overall system efficiencies and the amount of energy stored and released.
\end{abstract}

Keywords: solar organic Rankine cycle; direct vapor generation; phase change material; efficiency; net power output; energy stored 


\section{Introduction}

The low-temperature and waste-heat to power conversion can significantly improve energy efficiency and reduce environmental pollution. There are several technologies for low-temperature and waste-heat to power conversion, including Kalina cycle [1], Goswami cycle [2], trilateral flash cycle [3], etc. The organic Rankine cycle [4] remains the most promising in practice.

The working principle of the organic Rankine cycle is similar to a conventional steam Rankine cycle. A high molecular mass organic working fluid with a lower saturated boiling temperature is used as a working fluid in the organic Rankine cycle (ORC). The higher molecular weight of organic fluid as compared to water results in an increase in the mass flow rate for the turbine of the same size [5]. Hence, the larger mass flow rate results in higher thermal efficiency. Moreover, the lower boing point temperature of organic fluid makes it suitable for the low-temperature application.

Solar thermal energy is a relatively new application of the ORC system as compared to biomass, waste heat recovery, or geothermal energy sources. Since the temperature of about $100^{\circ} \mathrm{C}$ or slightly higher is sufficient to drive the ORC [6], solar thermal energy is a potential heat source for the organic Rankine cycle. There are two kinds of solar ORC systems reported in the past namely direct and indirect solar ORC systems [7]. The indirect solar ORC system (conventional solar ORC system) is one in which heat transfer fluid (HTF) is used to collect heat from solar collectors and then release it to the organic fluid through the intermediate heat exchanger. The direct solar ORC system does not employ an intermediate heat exchanger, and the working fluid flows through the collector and ORC system. Therefore, solar collectors serve as an evaporator in the case of a direct solar ORC system [8].

In recent years, the direct solar ORC system (also known as direct vapor generation (DVG) solar ORC system) has gotten significant attention. Some researchers have conducted experimental work $[9,10]$ while others have carried out theoretical studies [11-13]. The selection of working fluids and performance evaluation of the system has remained the top priority among the researchers. The direct vapor generation solar ORC system has shown a high thermal match with fluctuating solar radiation. Hence, it has relatively higher thermal efficiencies and net power output in comparison with the conventional solar ORC system [7].

Solar collectors are an integral part of a solar ORC system. They are generally divided into concentrating and non-concentrating solar collectors. The concentrating collectors utilize beam (direct) radiation while non-concentrating collectors use both beam and diffuse solar radiation [14]. The selection of solar collectors for the DVG solar ORC system can be critical due to its high operating pressure inside the collector's tube. Therefore, the solar collectors that are designed and tested to operate at high pressure can be employed in DVG applications. Apart from the widely used parabolic trough collectors (PTC) and the evacuated tube heat pipe collectors, U-type and Cylindrical-type CPC collectors, and evacuated flat plate collectors (EFPCs) are good candidates [15]. These collectors can work with high efficiency 
at a very high operating pressure [16,17]. For the evacuated flat plate collectors, they can offer work at over $50 \%$ efficiency at temperatures of $200^{\circ} \mathrm{C}$ due to the high-vacuum inside. In contrast to concentrating systems, the collector can also utilize diffuse irradiation and without any tracking device [18]. Hence, non-concentrating, non-tracking and less-cleaning solar collectors are preferred for solar ORC systems $[19,20]$.

The selection of appropriate thermal storage for thermal power generation systems is a critical and challenging task. Two types of thermal storages have been reported in the past namely Sensible Heat Storages (SHS) and Latent Heat Storage (LHS) [20]. Phase Change Material (PCM) storage is one type of LHS. This kind of heat storage is found to be promising and efficient due to its high energy density as compared to SHS. It is observed that PCMs can store 5-14 times extra energy per unit volume in comparison with SHS [21]. Moreover, they are also beneficial due to maximum heat storage occurs at nearly isothermal temperature. However, they have some disadvantages associated with them such as low thermal conductivity, flammability and sub-cooling [22].

The PCMs can be divided into three groups depending upon transition phases [23]. They are solid to liquid, liquid to gas and gas to the liquid phase transition. The solid to liquid phase transition being major classification is further subdivided into organic, in-organic and eutectics. There are many pros and cons of PCMs depending upon their classification [24]. For example, organic PCMs are advantageous because of their very high chemical stability, less sub-cooling and corrosion issues, good compatibility with different types of containers, and high availability in different temperature ranges. However, they have disadvantages of high flammability, low thermal conductivity and larger volume changes. Similarly, Inorganic PCMs are beneficial because of the higher amount of latent heat, high thermal conductivity, low volume changes, low cost and no flammability. However, there are some disadvantages associated with in-organic PCMs such as highly corrosive nature, high degree of subcooling and non-compatibility with micro and nano capsulation techniques. Moreover, eutectic PCMs have advantages of high thermal conductivity, high energy density and sharp phase changes. However, this type of PCMs has limited availability and high cost $[21,25]$. The PCMs can also be divided into low temperature $\left(<60^{\circ} \mathrm{C}\right)$, medium temperature $\left(60-150^{\circ} \mathrm{C}\right)$ and high temperature $\left(>150^{\circ} \mathrm{C}\right)$ ranges depending upon their melting point temperatures [26]. However, medium temperature range PCMs are suitable for the solar ORC system.

The incorporation of PCMs with solar power plants can be a viable option [27]. The exergoeconomic performance of the PCM based solar power plant is carried out by Abbasi et al. [28,29]. It was found that the use of PCMs leads to the continuous operation of the power plant. The Levelized Cost of Electricity (LCoE) has shown a downward trend of concentrated solar plants. Recent studies are focused on the decreasing thermal resistance between heat transfer fluid and PCM to increase the heat extraction rate [30]. 
The integration of PCM with solar ORC system has gotten attention during the past decade as shown in

Table 1.

Table 1: Previously reported solar organic Rankine cycle system integrated with phase change materials storage

\begin{tabular}{|c|c|c|c|}
\hline Ref. & PCM tested & $\begin{array}{l}\text { System } \\
\text { description }\end{array}$ & Objectives and Findings \\
\hline$[14,31]$ & $\begin{array}{l}\mathrm{MgCl}_{2} \cdot 6 \mathrm{H}_{2} \mathrm{O} \\
\mathrm{NaCH}_{3} \mathrm{CO}_{2} \cdot 3 \mathrm{H}_{2} \mathrm{O} \\
\text { erythritol }\end{array}$ & $\begin{array}{l}\text { Cascade solar } \\
\text { ORC system }\end{array}$ & $\begin{array}{l}\text { The two-staged PCMs are employed to increase heat transfer } \\
\text { between PCM and working fluid. The melting point of } 1^{\text {st }} \\
\text { stage PCM is lower than } 2^{\text {nd }} \text { stage PCM. }\end{array}$ \\
\hline$[32]$ & A164 & $\begin{array}{l}\text { The indirect or } \\
\text { conventional } \\
\text { solar ORC } \\
\text { system }\end{array}$ & $\begin{array}{l}\text { The modeling of PCM is done using the enthalpy method. } \\
\text { Simulation is carried out for } 10 \text { days. The overall system } \\
\text { performance has increased by using PCM container having a } \\
\text { smaller diameter and longer length. }\end{array}$ \\
\hline [23] & $\mathrm{MgCl}_{2} \cdot 6 \mathrm{H}_{2} \mathrm{O}$ & $\begin{array}{l}\text { The indirect or } \\
\text { conventional } \\
\text { solar ORC } \\
\text { system }\end{array}$ & $\begin{array}{l}\text { Simulation and modeling of PCM are carried out for } 7 \text { days. } \\
\text { The efficiency of PCM is calculated on a weekly average } \\
\text { basis. It is found to be } 83 \% \text { and } 93 \% \text { during charging and } \\
\text { discharging mode, respectively. }\end{array}$ \\
\hline [33] & $\begin{array}{l}\text { Erythritol, } \\
\mathrm{MgCl}_{2} \cdot 6 \mathrm{H}_{2} \mathrm{O}\end{array}$ & $\begin{array}{l}\text { The indirect or } \\
\text { conventional } \\
\text { solar ORC } \\
\text { system }\end{array}$ & $\begin{array}{l}\text { Thermal analysis of PCM is carried out using a heat capacity } \\
\text { method. Erythritol has stored } 30 \% \text { more energy as compared } \\
\text { to } \mathrm{MgCl}_{2} \cdot 6 \mathrm{H}_{2} \mathrm{O} \text {. }\end{array}$ \\
\hline [5] & $\begin{array}{l}\text { Organic and } \\
\text { Inorganic PCMs }\end{array}$ & $\begin{array}{l}\text { The indirect or } \\
\text { conventional } \\
\text { solar ORC } \\
\text { system }\end{array}$ & $\begin{array}{l}\text { Different combinations of PCMs and water storage are } \\
\text { employed in a small-scale solar ORC system. It is found that } \\
\text { PCMs have shown } 20 \% \text { more daily electrical output per unit } \\
\text { storage volume as compared to water storage }\end{array}$ \\
\hline$[34,35]$ & Solar salt & $\begin{array}{l}\text { The indirect or } \\
\text { conventional } \\
\text { solar ORC } \\
\text { system }\end{array}$ & $\begin{array}{l}\text { A PCM storage tank is designed to employ it in a solar ORC } \\
\text { system with a thermal capacity of } 100 \mathrm{~kW} \text {. It is found that the } \\
\text { use of aluminum fins lower the temperature gradient across } \\
\text { the PCM storage tank. }\end{array}$ \\
\hline$[7,8]$ & $\mathrm{MgCl}_{2} \cdot 6 \mathrm{H}_{2} \mathrm{O}$ & $\begin{array}{l}\text { DVG and indirect } \\
\text { solar ORC } \\
\text { system }\end{array}$ & $\begin{array}{l}\text { Thermodynamic comparison of DVG and indirect solar ORC } \\
\text { system is carried out. The thermal match between PCM and } \\
\text { organic fluid is found to be stronger in comparison with PCM } \\
\text { and water. }\end{array}$ \\
\hline
\end{tabular}


The previous studies on PCM based solar ORC system were generally focused on simulation, modeling and performance evaluation. Furthermore, most of the studies were based on an indirect solar ORC system and a limited number of PCMs were investigated. However, the detailed research on the effect of different PCMs (organic, inorganic and ecutic) on the DVG solar ORC system has not yet been reported. The novelty of the present work lies in the performance evaluation of the DVG solar ORC system using 12 different PCMs. The contribution includes

Development and validation of the model of the PCM storage tank with experimental and numerical 113 data.

114 Effect of evaporation temperature and working fluid mass flow rate on the system's performance.

115 The evaluation and comparison of variation in collector, ORC and system efficiency during charging 116 and discharging mode of the PCM, respectively.

117 The evaluation and comparison of net power output, amount of heat stored and released during charging 118 and discharging mode.

119 This study will serve as a bench reference for the future work in the area of solar ORC system with 120 integrated thermal energy storage. It will facilitate the design engineers to choose the suitable phase 121 change material based on the performance of the ORC system.

\section{2. The proposed system configuration}

123 The layout diagram of the proposed DVG solar ORC system is shown in Figure 1. The proposed system 124 consists of an array of evacuated flat plate collectors, phase change material storage tank, organic fluid 125 pump, condenser and turbine coupled with a generator. The array of EFPCs works as an evaporator 126 (direct vapor generator) in the present system. The PCM storage tank operates in two-mode namely charging and discharging mode. Moreover, the basic solar ORC system is considered which does not require complicated control strategy. 


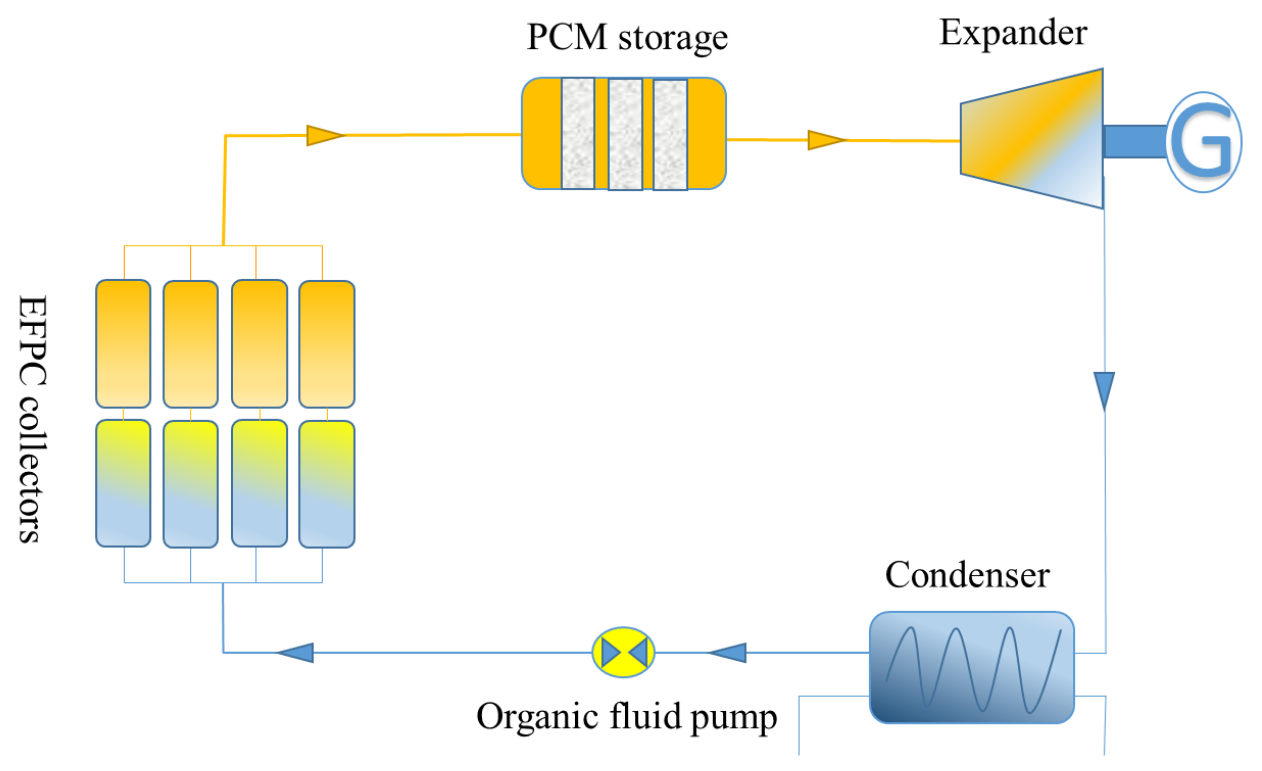

In practical, there can be two modes of operation:

(a) The system undergoes charging mode if the temperature of PCM is less than the evaporation temperature $\left(\mathrm{T}_{\mathrm{evp}}>\mathrm{T}_{\mathrm{pcm}}\right)$.

(b) The system undergoes discharging mode if the temperature of PCM is greater than the evaporation temperature $\left(\mathrm{T}_{\mathrm{evp}}<\mathrm{T}_{\mathrm{pcm}}\right)$.

The whole process consists of evaporation, expansion, condensation and pressurization. The working fluid is firstly heated up to specified evaporation temperature in an array of EFPC solar thermal collectors. The collectors collect heat from solar radiation and carry it to the working fluid. Then the working fluid passes through the PCM storage tank to either absorb heat during charging mode or extract heat during discharging mode. The working fluid then enters the expander in a saturated vapor phase to deliver power output while dropping the pressure. Afterward, it is cooled down in the condenser to the subcooled liquid phase. Finally, the working fluid is used to pressurize in the working fluid pump to transfer it back to the solar collectors.

Hourly based climatic data of Hefei-China has been used for the current study. Typical meteorological year (TMY) data of Hefei is obtained by using Meteonorm software [36]. The data is imported in MATLAB to carry out dynamic simulation of PCM based DVG solar ORC system. It is assumed that the system starts working when the solar radiation received at the surface of the collector goes above $400 \mathrm{~W} / \mathrm{m}^{2}$. On the contrary, the system stops or undergoes to discharging mode. The initial temperature of PCM is assumed to be $10^{\circ} \mathrm{C}$ lower than the melting point of the PCM. This shows that PCM is not charged and in the solid phase at the beginning of the simulation process. The discharging limit of the storage tank is maintained to $20^{\circ} \mathrm{C}$ lower than the melting point of the PCM, which means that the system is allowed to discharge the storage in a sensible heat region. 
153

154

155

156

157

158

159

160

161

162

163

164

165

166

167

168

169

170

171

172

173

174

175

176

177

178

179

180

181

\section{Thermodynamic modeling}

\subsection{Solar radiation}

Solar radiation received by the sloped surface of the solar collectors is calculated by [37]. The solar collectors are titled at an angle equal to the latitude of Hefei city China.

$G_{t}=\left(G_{b}+G_{d} \frac{G_{b}}{G_{h}}\right) R_{b}+I_{d}\left(1-\frac{G_{b}}{G_{h}}\right)\left(\frac{1+\cos \beta}{2}\right)\left(1+\sqrt{\frac{G_{b}}{G_{h}}} \operatorname{Sin}^{3}\left(\frac{\beta}{2}\right)\right)+G_{h} \rho_{g}\left(\frac{1-\cos \beta}{2}\right)$

\subsection{Solar thermal collectors}

An array of the evacuated flat plate collectors is employed in the direct vapor generation solar ORC system. The evacuated flat plate collectors are advantageous because of high efficiency at high operating temperatures. They are also advantageous because of their non-tracking, non-concentrating and stationary nature. Moreover, they utilize both diffused and beam radiation which makes them beneficial in the areas having less solar resources [18]. The thermal efficiency of the solar collector is generally derived using a heat loss formula [4].

$$
\eta_{c l}(T)=\eta_{c l, 0}-\frac{A}{G}\left(T-T_{a m b}\right)-\frac{B}{G}\left(T-T_{a m b}\right)^{2}
$$

Where the optical efficiency $\eta_{c l, o}$ is 0.774 , primary heat loss coefficient $A$ of solar collectors is 0.376 $\mathrm{Wm}^{-2}{ }^{\circ} \mathrm{C}^{-1}$ and the secondary heat loss coefficient $\mathrm{B}$ is $0.006 \mathrm{Wm}^{-2}{ }^{\circ} \mathrm{C}^{-2}[5,38]$. The Eq. (2) is generally used for efficiency calculation of a single module that is commercially available having a surface area in a range of 1-2 $\mathrm{m}^{2}$. However, in the case of hundreds of square meters of solar collector area, the temperature difference between adjacent collectors is small. Therefore, it is appropriate to suppose that the average operating temperature of the collector varies from one to another module. The organic fluid in the collectors' array is found to be in liquid and vapor phases respectively. The average temperature of the collector remains constant during the binary phase. Hence, the collector efficiency can be computed by using Eq. (2) [11]. In the case of the liquid region, the temperature varies across the collector. The surface area of the collector can be calculated by Eq. (3).

$$
S_{l}=\int_{T_{f, i}}^{T_{f, o}} \frac{m_{f} C_{p, f}(T)}{\eta_{c l}(T) G} d T
$$

The thermal heat capacity of organic fluid can be computed by a first-order approximation

$$
C_{p}(T)=C_{p, \mathrm{o}}+\alpha\left(T-T_{\mathrm{O}}\right)
$$

By putting $a_{1}=A / G, \quad a_{2}=B / G$, the solar collector area can be computed by using Eqs. (2), (3) and (4) 


$$
S_{l}=\frac{m_{f}}{c_{2} G\left(\theta_{2}-\theta_{1}\right)}\left[\left(C_{p, a}+\alpha \theta_{1}\right) \ln \frac{\left(T_{f, o}-T_{a m b}-\theta_{1}\right)}{T_{f, i}-T_{a m b}-\theta_{1}}+\left(C_{p, a}+\alpha \theta_{2}\right) \ln \frac{\theta_{2}-T_{f, i}+T_{a m b}}{\theta_{2}-T_{f, o}+T_{a m b}}\right]
$$

183

184

185

Where, $\theta_{1}$ and $\theta_{2}$ are the arithmetical solutions of Eq. (6) $\theta_{1}<0, \theta_{2}>0$.

$$
\begin{aligned}
& \eta_{o}-a_{1} \theta-a_{2} \theta^{2}=0 \\
& C_{p, a}=C_{p, 0}+\alpha\left(T_{a m b}-T_{0}\right)
\end{aligned}
$$

Solar collectors' efficiency in the liquid phase can be computed by

$$
\eta_{c l, l}=\frac{m_{f}\left(h_{l, o}-h_{l, i}\right)}{G S_{l}}
$$

Solar collectors' efficiency having working fluid in the vapor phase and the thermal efficiency of the overall collector array is computed by Eq. (9) and Eq. (10), respectively.

$$
\begin{gathered}
\eta_{c l, v}=\frac{m_{f}\left(h_{b, o}-h_{b, i}\right)}{G S_{b}} \\
\eta_{c l}=\frac{m_{f}\left(h_{b, o}-h_{l, i}\right)}{G\left(S_{l}+S_{b}\right)}
\end{gathered}
$$

\subsection{Phase change material storage}

Figure 2 presents the layout diagram of the double pipe heat exchanger filled with PCM. The multi tubes are incorporated in the big cylindrical shell as shown in part (a) of Figure 2. Moreover, each tube is comprised of a small diameter tube (mini-tube) incorporated in a large diameter tube as shown in part (b) of figure 2. The larger cylindrical tube is filled with PCM while the organic fluid is passed through mini-tube. The length of both of the tubes is kept the same. The diameter of the PCM tube is kept 10 times larger than the diameter of the fluid tube [7]. The volume of PCM storage tank is assumed to be $90 \mathrm{~m} 3$. The outside wall of the PCM tube and container is supposed to be insulated. The PCM storage tank operates in charging and discharging mode depending upon operating conditions. Heat transfer between organic fluid and PCM occurs through convection. However, heat transfer within PCM is assumed to be through conduction. The organic fluid transfers heat to PCM during charging mode. The temperature of the PCM increases from solid-phase until it approaches its melting point temperature. Afterward, the temperature of the PCM becomes constant during the whole melting process. The PCM changes into the liquid phase after the completion of the melting process. 


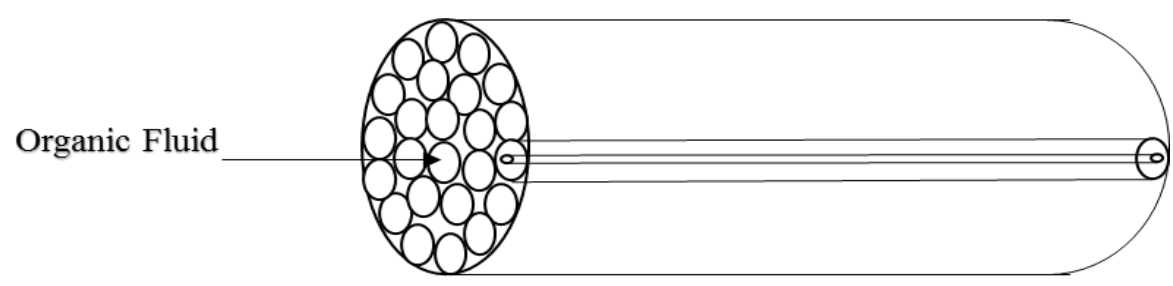

(a)

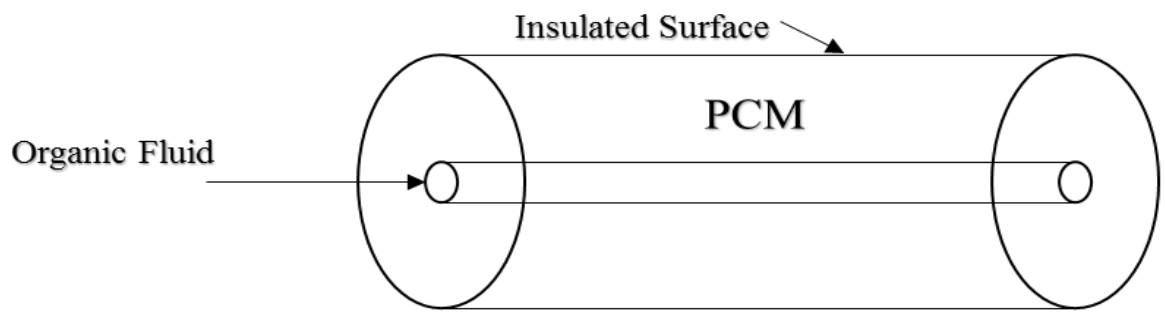

(b)

Figure 2: (a) Layout diagram of the PCM storage tank (b) The elemental unit (mini-tube) of the PCM storage tank

Conversely, heat is transferred from PCM to organic fluid during the discharging mode. The PCM changes from liquid to solid phase by releasing heat to the organic fluid. The famous Enthalpy method is used to model the PCM storage tank $[39,40]$. To develop the mathematical model for the movement of heat through PCM few assumptions are made as follows:

- Conductive heat transfer is considered to be the dominant mechanism within the PCM.

- Only One-dimensional heat transfer is contemplated.

- Thermo-physical properties of the PCM remains constant during each state.

- Natural convections can happen due to density difference which is neglected in this model.

$$
\rho \frac{\partial H}{\partial t}=\kappa_{p c m} \frac{\partial^{2} T_{p c m}}{\partial y^{2}}
$$

Where the total volumetric enthalpy is depicted by " $\mathrm{H}$ ". It is a combination of both the sensible and the latent heat of PCM at a given temperature [41]. Hence, at any given temperature, the total volumetric enthalpy of PCM can be computed by Eq. (12)

$$
H=\int_{T_{m}}^{T} \rho_{p c m} C_{p c m} d T_{p c m}+\rho_{p c m} L F(\lambda)
$$

The latent heat of the PCM is related to the liquid fraction of the PCM "LF" and density of PCM " $\rho_{p c m}$ ". To calculate the latent heat of the PCM, the liquid fraction LF must be known. Hence, LF can be calculated by the following relation

$$
L F=\left\{\begin{array}{cccc}
0 & \text { for } & T_{p c m}<T_{m} & \text { Solid region } \\
1 & \text { for } & T_{p c m}>T_{m} & \text { Liquid region }
\end{array}\right.
$$


The PCM lies in the solid or liquid region is depicted by its LF value. If the value of LF $=0$ it means the PCM is in the solid phase. However, if the value of LF $=1$ this shows the PCM in the liquid region. Moreover, the sensible enthalpy of the PCM can be calculated by Eq. (14)

$$
h(T)=\int_{T_{m}}^{T} \rho_{p c m} C_{p c m} d T_{p c m}
$$

From equation (11) and (13) the enthalpy of PCM can be computed by

$$
H=\left\{\begin{array}{llll}
\rho_{p c m} C_{p c m}\left(T_{p c m}-T_{m}\right) & \text { for } & T_{p c m}<T_{m} & \text { Solid region } \\
\rho_{p c m} C_{p c m}\left(T_{p c m}-T_{m}\right)+\lambda \rho_{p c m} & \text { for } & T_{p c m}>T_{m} & \text { Liquid region }
\end{array}\right.
$$

The Eq. (14) shows that if the PCM is lying in a solid region, it only contains sensible heat. However, if the PCM lies in the liquid region, it contains both latent and sensible heat. The volumetric enthalpy of the PCM can be used to derive the temperature of the PCM "T $\mathrm{p}_{\mathrm{pcm}}$ " as shown in Eq. (16)

$$
T_{p c m}=\left\{\begin{array}{ccc}
T_{m}+\frac{H}{\rho_{p c m} \cdot C_{p c m}} & \text { for } & H<0 \\
T_{m} & \text { for } & 0<H<\rho_{p c m} \cdot \lambda \\
T_{m}+\frac{H-\left(\rho_{p c m} \cdot \lambda\right)}{\rho_{p c m} \cdot C_{p c m}} & \text { for } & H>\rho_{p c m} \cdot \lambda
\end{array}\right.
$$

Where $\lambda$ is the latent heat of the PCM while $\rho_{\mathrm{pcm}}$ is the density of PCM. By employing Eq. (12) and Eq. (13) an alternative form of Eq. (10) for one-dimensional heat transfer within the PCM can be computed as follows:

$$
\frac{\partial h}{\partial t}=\frac{\partial}{\partial y}\left(\alpha \frac{\partial h}{\partial y}\right)-\rho_{p c m} \lambda\left(\frac{\partial L F}{\partial t}\right)
$$

Furthermore, the amount of heat stored by the PCM during charging and discharging mode is computed by multiplying the total mass of the PCM " $M_{p c m}$ " with the difference in specific enthalpy between a final and initial node of the PCM storage tank as depicted in Eq. (18)

$$
Q_{s t}=M_{p c m}\left(h_{\mathrm{mx}}-h_{i n}\right)
$$

Similarly, the amount of heat released during discharging mode is calculated by multiplying the difference in specific enthalpy between an initial and final node of the PCM storage tank with the total mass of the PCM “ $M_{p c m}$ " as shown in Eq. (19)

$$
Q_{\text {rel }}=M_{p c m}\left(h_{i n}-h_{m x}\right)
$$

The total mass of PCM can be calculated by using Eq. (20)

$$
M_{p c m}=\pi\left(r_{p c m}^{2}-r_{\text {fluid }}^{2}\right) \times L_{p c m} \times \rho_{p c m}
$$


Where $\mathrm{r}$ is the radius, $\mathrm{L}$ is the length and $\rho$ is the density, respectively. A reliable numerical simulation model of the PCM storage tank is developed using the finite difference method in MATLAB programming environment and results are validated against experimental results presented in the literature. The PCM model is then incorporated into the solar ORC system. Thermo-physical properties of the PCMs used in the present study are shown in Table 2.

Table 2: Thermo-physical properties of the PCMs employed in DVG solar ORC system

\begin{tabular}{|c|c|c|c|c|c|c|}
\hline Compound & $\begin{array}{l}\text { Mass Ratio } \\
\text { (\%) }\end{array}$ & $\begin{array}{c}T_{m} \\
\left({ }^{\circ} \mathrm{C}\right)\end{array}$ & $\begin{array}{l}\text { Latent heat of PCM } \\
(\mathrm{kJ} / \mathrm{kg})\end{array}$ & $\begin{array}{c}C_{p c m} \\
(\mathrm{~kJ} / \mathrm{kg}-\mathrm{K})\end{array}$ & $\begin{array}{c}K_{p c m} \\
\left(\mathrm{~W} / \mathrm{m}^{2}-\mathrm{K}\right)\end{array}$ & $\begin{array}{c}\rho_{p c m} \\
\left(\mathrm{~g} / \mathrm{m}^{3}\right)\end{array}$ \\
\hline \multicolumn{2}{|c|}{ Acetamide } & 82 & 260 & 2.5 & 0.35 & 1160 \\
\hline \multicolumn{2}{|c|}{ Erythritol } & 117 & 340 & 2.42 & 0.53 & 1450 \\
\hline \multicolumn{2}{|c|}{ HDPE } & 130 & 255 & 2.38 & 0.46 & 952 \\
\hline \multicolumn{2}{|c|}{ Urea } & 134 & 250 & 1.95 & 0.7 & 1320 \\
\hline \multicolumn{2}{|c|}{$\mathrm{Mg}\left(\mathrm{NO}_{3}\right)_{2} .6 \mathrm{H}_{2} \mathrm{O}$} & 89 & 140 & 2.78 & 0.58 & 1640 \\
\hline \multicolumn{2}{|c|}{$\mathrm{C}_{2} \mathrm{H}_{2} \mathrm{O}_{6}$} & 105 & 264 & 2.5 & 0.8 & 1653 \\
\hline \multicolumn{2}{|c|}{$\mathrm{MgCl}_{2} .6 \mathrm{H}_{2} \mathrm{O}$} & 116.7 & 150 & 2.6 & 0.6 & 1570 \\
\hline Urea-NaCl & $90-10$ & 112 & 230 & 1.87 & 0.71 & 1372 \\
\hline Urea-KCl & $89-11$ & 115 & 227 & 1.83 & 0.71 & 1370 \\
\hline $\mathrm{LiNO}_{3}-\mathrm{KNO}_{3}$ & $34-66$ & 133 & 150 & 1.26 & 0.74 & 2018 \\
\hline $\mathrm{KNO}_{3}-\mathrm{NaNO}_{2}$ & $56-44$ & 141 & 97 & 1.46 & 0.65 & 1994 \\
\hline $\mathrm{KNO}_{2}-\mathrm{NaNO}_{3}$ & $48-52$ & 149 & 124 & 1.34 & 0.55 & 2080 \\
\hline
\end{tabular}

\subsection{Validation of the numerical model}

257 The numerical simulation model is developed to evaluate the performance of PCM storage containers.

258 The results obtained by the present model is then validated by experimental and numerical results of 259 Nallusamy et al. [42] and Mosaffa et al. [43], respectively. Figure 3 shows the comparison between the experimental results of Nallusamy et al. [42] and the current computational model. An insulated cylindrical PCM storage tank was having a capacity of 47 liters (460 $\mathrm{mm}$ height and $360 \mathrm{~mm}$ diameter) was used to carry out the performance test. There were 264 spherical capsules uniformly placed inside the container. The paraffin having melting point temperature $60^{\circ} \mathrm{C}$ was used as PCM and water worked as HTF. The results of the experiment by Nallusamy et al. [42] are reproduced using a current computational model. The results are reproduced for a case when HTF and PCM temperatures were taken at $\mathrm{x} / \mathrm{l}$ (dimensionless axial distance from the top of the PCM storage tank) $=1.0$. There is a good agreement found between the numerical and experimental results as shown in Figure 3. The thermophysical properties of the PCM used to experiment by Nallusamy et al. [42] are presented in Table 3. 
Table 3: Thermo-Physical properties of Paraffin used by Nallusamy et al. [42]

\begin{tabular}{|l|c|c|}
\hline \multicolumn{2}{|l|}{} & 60 \\
\hline \multicolumn{2}{|l|}{ Melting Point $\left({ }^{\circ} \mathrm{C}\right)$} & 213 \\
\hline \multirow{2}{*}{ Density $\left(\mathrm{kg} / \mathrm{m}^{3}\right)$} & Solid & 861 \\
\hline \multirow{2}{*}{ Thermal conductivity $\left(\mathrm{W} / \mathrm{m}^{2}-\mathrm{K}\right)$} & Liquid & 778 \\
\cline { 2 - 3 } & Solid & 0.4 \\
\hline \multirow{2}{*}{ Specific heat capacity $(\mathrm{kJ} / \mathrm{kg}-\mathrm{K})$} & Liquid & 0.15 \\
\cline { 2 - 3 } & Solid & 1.85 \\
\cline { 2 - 3 } & Liquid & 2.384 \\
\hline
\end{tabular}

271

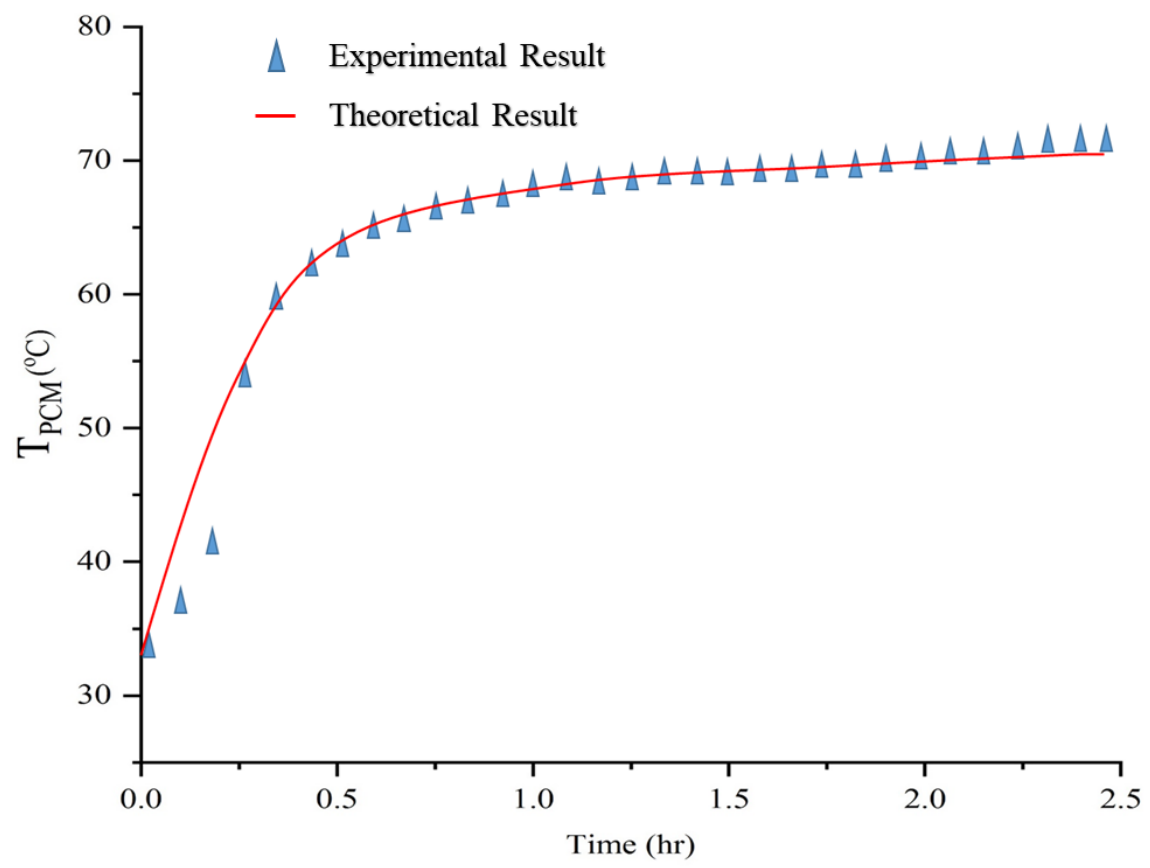

Figure 3: Comparison of the PCM modeling results with Nallusamy et al. [42] for the melting of PCM

The results of the current computational model are also validated against the theoretical results of

275 Mosaffa et al. [43]. $\mathrm{CaCl}_{2} 6 \mathrm{H}_{2} \mathrm{O}$ was used as PCM. The PCM had a melting point of $29^{\circ} \mathrm{C}$ and air worked

276 as HTF. Thermo-physical properties of the PCM used by Mosaffa et al. [43] are shown in Table 4. The

277 results are reproduced for $\mathrm{CaCl}_{2} \cdot 6 \mathrm{H}_{2} \mathrm{O}$ using the current computational model and compared with the results of Mosaffa et al. [43] as shown in Figure 4.

Table 4: Thermo-Physical properties of $\mathrm{CaCl}_{2} .6 \mathrm{H}_{2} \mathrm{O}$

\begin{tabular}{|c|c|c|}
\hline \multicolumn{2}{|l|}{ Melting Point $\left({ }^{\circ} \mathrm{C}\right)$} & 29 \\
\hline \multicolumn{2}{|l|}{ Latent heat $(\mathrm{kJ} / \mathrm{kg})$} & 187 \\
\hline \multirow{2}{*}{ Density $\left(\mathrm{kg} / \mathrm{m}^{3}\right)$} & Solid & 1710 \\
\hline & Liquid & 1530 \\
\hline Thermal conductivity $\left(\mathrm{W} / \mathrm{m}^{2}-\mathrm{K}\right)$ & Solid & 1.09 \\
\hline
\end{tabular}




\begin{tabular}{|l|c|c|}
\hline & Liquid & 0.53 \\
\hline \multirow{2}{*}{ Specific heat capacity $(\mathrm{kJ} / \mathrm{kg}-\mathrm{K})$} & Solid & 1.4 \\
\cline { 2 - 3 } & Liquid & 2.2 \\
\hline
\end{tabular}

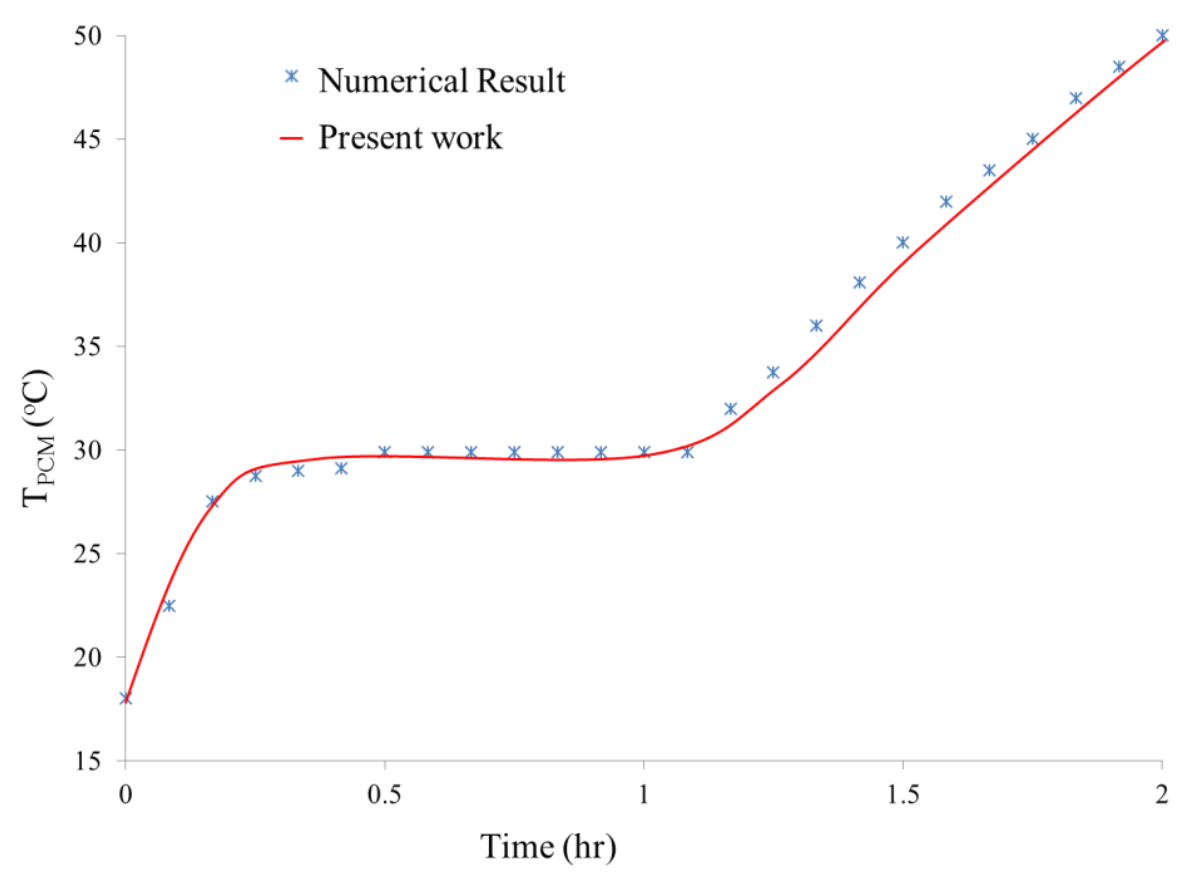

It is observed that results obtained by using the current computational model have shown good agreement with the results of Mosaffa et al. [43].

\subsection{Organic Rankine cycle}

The basic and subcritical ORC is considered in this study because of its low cost, less technical demand and suitability for low-medium temperature applications. Evaporation and condensation processes are assumed to be isobaric while expansion and pressurization processes are adiabatic. There are some assumptions and operating conditions chosen for present work as shown in table 5 .

Table 5: The operating and boundary conditions assumed for the ORC system

\begin{tabular}{|l|l|}
\hline Parameter & Value \\
\hline Turbine efficiency for initial cycle design [15] & $80 \%$ \\
\hline Pump efficiency for initial cycle design [44] & $60 \%$ \\
\hline Generator efficiency & $85 \%$ \\
\hline Condensation temperature & $30^{\circ} \mathrm{C}$ \\
\hline
\end{tabular}


R123 has been widely accepted as a suitable working fluid for low-temperature ORC applications but no working fluid is perfect and ideal. R123 has a suitable evaporator, condenser pressure, safe for use, 0 ODP but has a GWP, which allows the further search of a better-working fluid in the low-temperature range [11]. The expander power output and power consumption by the pump are computed by Eq. (21) and Eq. (22), respectively.

$$
w_{t}=m\left(h_{t, i}-h_{t, o}\right)
$$

$$
w_{p}=m\left(h_{p, o}-h_{p, i}\right)
$$

The expander and pump isentropic efficiency can be computed by Eq. (23) and Eq. (24), respectively.

$$
\begin{gathered}
\varepsilon_{t}=\frac{h_{t, i}-h_{t, o}}{h_{t, i}-h_{t, o s}} \\
\varepsilon_{p}=\frac{h_{p, o s}-h_{p, i}}{h_{p, o}-h_{p, i}}
\end{gathered}
$$

302

303

304

305

306

Where the ideal thermodynamic process is presented by os. The amount of energy utilized in the heating process of the ORC is computed by multiplying the mass flow rate of organic fluid with a rise in the enthalpy of organic fluid from the pump to the expander.

$$
q=m\left(h_{t, i}-h_{p, o}\right)
$$

Finally, the ORC efficiency can be computed by dividing the net power output to the amount of heat supplied as shown in Eq. (25).

$$
\eta_{\text {ORC }}=\frac{w_{t} \cdot \varepsilon_{g}-w_{p}}{q}
$$

The overall electricity efficiency of the DVG solar ORC can be computed by

$$
\eta_{s y s}=\eta_{O R C} \cdot \eta_{c l}
$$

\begin{tabular}{|c|c|c|c|c|c|c|c|c|c|c|c|c|c|c|c|}
\hline \multicolumn{2}{|l|}{ Compound } & \multicolumn{7}{|c|}{ Charging mode $\left(\mathrm{T}_{\mathrm{evp}}=\mathrm{T}_{\mathrm{m}}+10^{\circ} \mathrm{C}\right)$} & \multicolumn{7}{|c|}{ Discharging mode $\left(\mathrm{T}_{\mathrm{evp}}=\mathrm{T}_{\mathrm{m}}-10^{\circ} \mathrm{C}\right)$} \\
\hline & $\begin{array}{l}T_{m} \\
\left({ }^{\circ} \mathrm{C}\right)\end{array}$ & $\begin{array}{l}\eta_{c l} \\
(\%)\end{array}$ & $\begin{array}{c}w_{t} \\
(\mathrm{~kW})\end{array}$ & $\begin{array}{l}w_{p} \\
(\mathrm{~kW})\end{array}$ & $\begin{array}{c}\eta_{O R C} \\
(\%)\end{array}$ & $\begin{array}{l}\eta_{s y s} \\
(\%)\end{array}$ & $\begin{array}{l}\text { Pow } \\
(\mathrm{kW})\end{array}$ & $\begin{array}{l}Q_{s t} \\
(\mathrm{TJ})\end{array}$ & $\begin{array}{l}\eta_{c l} \\
(\%)\end{array}$ & $\begin{array}{c}w_{t} \\
(\mathrm{~kW})\end{array}$ & $\begin{array}{c}w_{p} \\
(\mathrm{~kW})\end{array}$ & $\begin{array}{l}\eta_{O R C} \\
(\%)\end{array}$ & $\begin{array}{l}\eta_{\text {sys }} \\
\text { (\%) }\end{array}$ & $\begin{array}{l}\text { Pow } \\
(\mathrm{kW})\end{array}$ & $\begin{array}{l}Q_{r e l} \\
\text { (TJ) }\end{array}$ \\
\hline Acetamide & 82 & 76.9 & 23.1 & 0.54 & 9.38 & 7.4 & 19.1 & 5.7 & 77.4 & 18.5 & 0.35 & 7.84 & 6.22 & 15.4 & 13.9 \\
\hline Erythritol & 117 & 72.8 & 34 & 1.29 & 12.5 & 9.36 & 27.6 & 4.49 & 75.8 & 29.6 & 0.92 & 11.4 & 8.83 & 24.3 & 9.34 \\
\hline HDPE & 130 & 69.5 & 37.4 & 1.69 & 13.4 & 9.54 & 30.1 & 2.04 & 74.1 & 33.3 & 1.22 & 12.3 & 9.39 & 27.1 & 4.91 \\
\hline Urea & 134 & 68 & 38.4 & 1.83 & 13.6 & 9.51 & 30.8 & 2.76 & 73.4 & 34.4 & 1.33 & 12.6 & 9.51 & 27.9 & 6.35 \\
\hline $\begin{array}{l}\mathrm{Mg}\left(\mathrm{NO}_{3}\right)_{2} \cdot 6 \mathrm{H}_{2} \\
\mathrm{O}\end{array}$ & 89 & 76.5 & 25.4 & 0.65 & 10.1 & 7.93 & 20.9 & 8.44 & 77.3 & 20.9 & 0.44 & 8.66 & 6.87 & 17.3 & 17.3 \\
\hline $\mathrm{C}_{2} \mathrm{H}_{2} \mathrm{O}_{6}$ & 105 & 74.8 & 30.5 & 0.98 & 11.6 & 8.9 & 24.9 & 6.47 & 76.7 & 26 & 0.69 & 10.3 & 8.11 & 21.4 & 13.1 \\
\hline
\end{tabular}

The thermodynamic performance of the DVG solar ORC system during both modes of operation using 12 different PCMs have been shown in table 6.

Table 6: The thermodynamic performance of the DVG solar ORC system during charging and discharging mode 


\begin{tabular}{|l|l|l|l|l|l|l|l|l|l|l|l|l|l|l|l|}
\hline $\mathrm{MgCl}_{2} \cdot 6 \mathrm{H}_{2} \mathrm{O}$ & 117 & 72.9 & 33.9 & 1.28 & 12.5 & 9.35 & 27.5 & 5.09 & 75.8 & 29.6 & 0.91 & 11.3 & 8.82 & 24.2 & 10.2 \\
\hline Urea-NaCl & 112 & 73.8 & 32.6 & 1.16 & 12.2 & 9.21 & 26.5 & 4.1 & 76.2 & 28.2 & 0.82 & 10.9 & 8.55 & 23.1 & 9.64 \\
\hline Urea-KCl & 115 & 73.2 & 33.4 & 1.24 & 12.4 & 9.31 & 27.2 & 3.91 & 76 & 29 & 0.88 & 11.2 & 8.72 & 23.8 & 9.14 \\
\hline $\mathrm{LiNO}_{3}-\mathrm{KNO}_{3}$ & 133 & 68.4 & 38.1 & 1.79 & 13.5 & 9.52 & 30.6 & 4.29 & 73.6 & 34.1 & 1.3 & 12.5 & 9.48 & 27.7 & 9.88 \\
\hline $\mathrm{KNO}_{3}-\mathrm{NaNO}_{2}$ & 141 & 64.8 & 39.9 & 2.09 & 13.9 & 9.31 & 31.9 & 3.77 & 72 & 36.1 & 1.53 & 13.1 & 9.65 & 29.2 & 8.47 \\
\hline $\mathrm{KNO}_{2}-\mathrm{NaNO}_{3}$ & 149 & 59.4 & 41.5 & 2.43 & 14.3 & 8.77 & 32.9 & 3.2 & 69.8 & 38 & 1.78 & 13.5 & 9.69 & 30.6 & 7.61 \\
\hline
\end{tabular}

\section{Results and Discussions}

317 In this section, firstly, the dynamic performance of the PCM based DVG solar ORC system is evaluated. $318 \mathrm{MgCl}_{2} \cdot 6 \mathrm{H}_{2} \mathrm{O}$ has been chosen as a case study. Weather data of Hefei city of China obtained by 319 Meteonorm software is incorporated in MATLAB to carry out the simulation process. The time chosen 320 for the simulation period is 24 hours. Hottest day of the year is taken as a reference day to simulate the 321 performance of PCM storage tank.

322 During the coldest day, the solar radiation $\left(\mathrm{G}<400 \mathrm{w} / \mathrm{m}^{2}\right)$ and ambient temperature are very low. Hence, 323 the energy available from solar collector array is not enough to run PCM storage tank. The proposed 324 system does not work under such a condition. Therefore, the performance of the system during coldest 325 day is not presented in this study.

326 Secondly, the instantaneous impact of the 12 PCMs on the performance of the DVG solar ORC system 327 concerning their melting point temperature is evaluated and compared during the charging and 328 discharging mode, respectively. The variation in the solar collector efficiency, the ORC efficiency, 329 overall system efficiency, and the net power output of the system with PCM melting point temperature 330 at given evaporation temperatures and mass flow rates are analyzed and discussed. Moreover, the effect 331 of melting point temperature of PCM on the rise and fall of organic fluid temperature, and the amount 332 of energy stored and released during charging and discharging mode is also analyzed.

\subsection{The dynamic performance of the PCM based DVG solar ORC system during the hottest week}

\subsubsection{Variation in the phase change material temperature and solar radiation with time}

336 To check the dynamic performance of the storage tank, $\mathrm{MgCl}_{2} \cdot 6 \mathrm{H}_{2} \mathrm{O}$ is selected as a case study. Figure 3375 shows the change in PCM temperature and solar radiation with time. The initial temperature of the $338 \mathrm{PCM}$ is selected to be $10^{\circ} \mathrm{C}$ lower than the melting point of the PCM. In the beginning, PCM temperature decreases till 8:00 AM, then it increases till 4:00 PM afterward it decreases again till midnight. Moreover, it is found that PCM storage is enough to run the system for the whole day. 


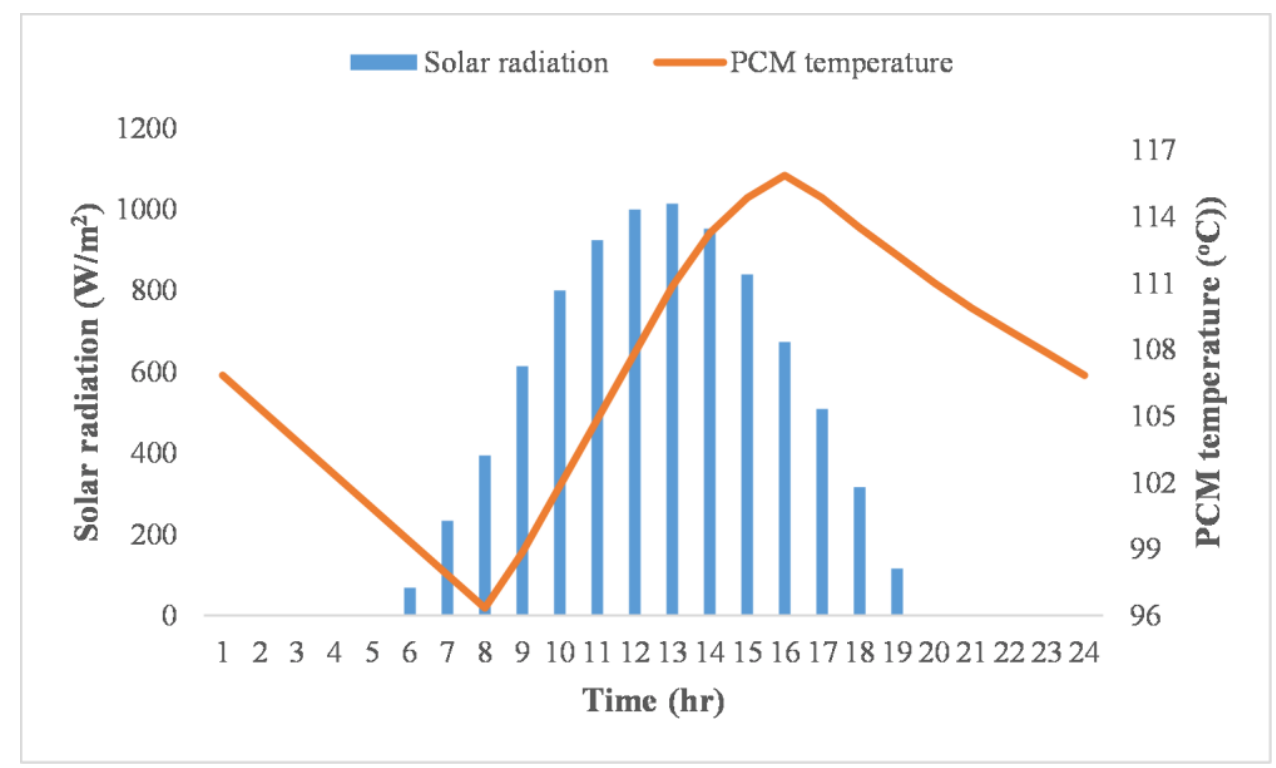

Figure 5: The change in PCM temperature and solar radiation revived at collector surface with time 4.1.2 Variation in collector and ORC efficiency with time

The performance of the PCM based DVG solar ORC system is analyzed. Figure 6 presents the change in collector and ORC efficiency with time. It has been found that ORC efficiency remains in the range of 10 to $12 \%$. However, solar collector efficiency remains in the range of 48 to $75 \%$. Hence, the solar ORC system works well for 24 hours.

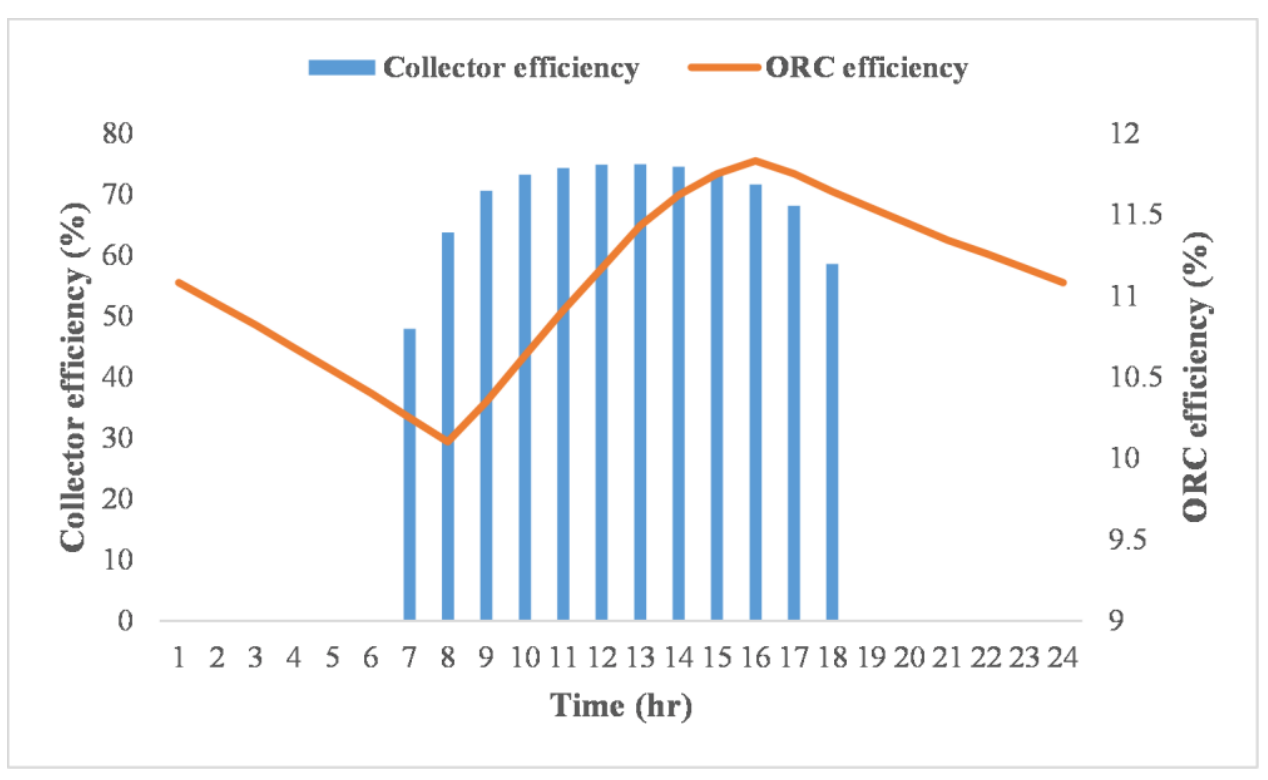

Figure 6: Variation in collector efficiency and ORC efficiency with time

\subsection{Instantaneous performance evaluation of the DVG solar ORC system at given evaporation temperature}

A basic subcritical ORC is considered in this study. The performance of the solar ORC system is evaluated at different levels of evaporation temperature. The evaporation temperature is kept $10^{\circ} \mathrm{C}$, $20^{\circ} \mathrm{C}$ and $30^{\circ} \mathrm{C}$ higher and lower than PCM melting point temperature to keep the system under charging 
and discharging mode, respectively. The standard value of irradiance of $1000 \mathrm{Wm}^{-2}$ and ambient temperature of $25^{\circ} \mathrm{C}$ is selected for simulation process.

\subsubsection{Impact of melting point temperature on ORC efficiency at given evaporation temperature}

ORC efficiency is one of the most important parameters to evaluate the performance of the organic Rankine cycle system. The variation in ORC efficiency with the melting point temperature of 12 different PCMs is shown in Figure 5. The ORC efficiency generally increases with increment in the melting point temperature, at a given evaporation temperature.

The PCMs are having higher melting point temperatures have shown the least increment with the increase in evaporation temperature while PCMs of lower melting points have shown maximum increment in ORC efficiency. For example, $\mathrm{KNO}_{2}-\mathrm{NaNO}_{3}$ has shown a minimum increment in ORC efficiency of $0.4 \%$ and $0.8 \%$ with the increase in evaporation temperature while Actemide has achieved a maximum increment of $1.46 \%$ and $1.1 \%$ during charging and discharging mode, respectively.

Relative increment in ORC efficiency is higher during discharging mode as compared to charging mode. For example, the ORC efficiency of $\mathrm{KNO}_{2}-\mathrm{NaNO}_{3}$ is $5.6 \%$ higher than Actemide during discharging mode while its value becomes $4.9 \%$ during charging mode. Conclusively, PCMs having higher melting points have shown overall better performance by achieving higher ORC efficiencies.
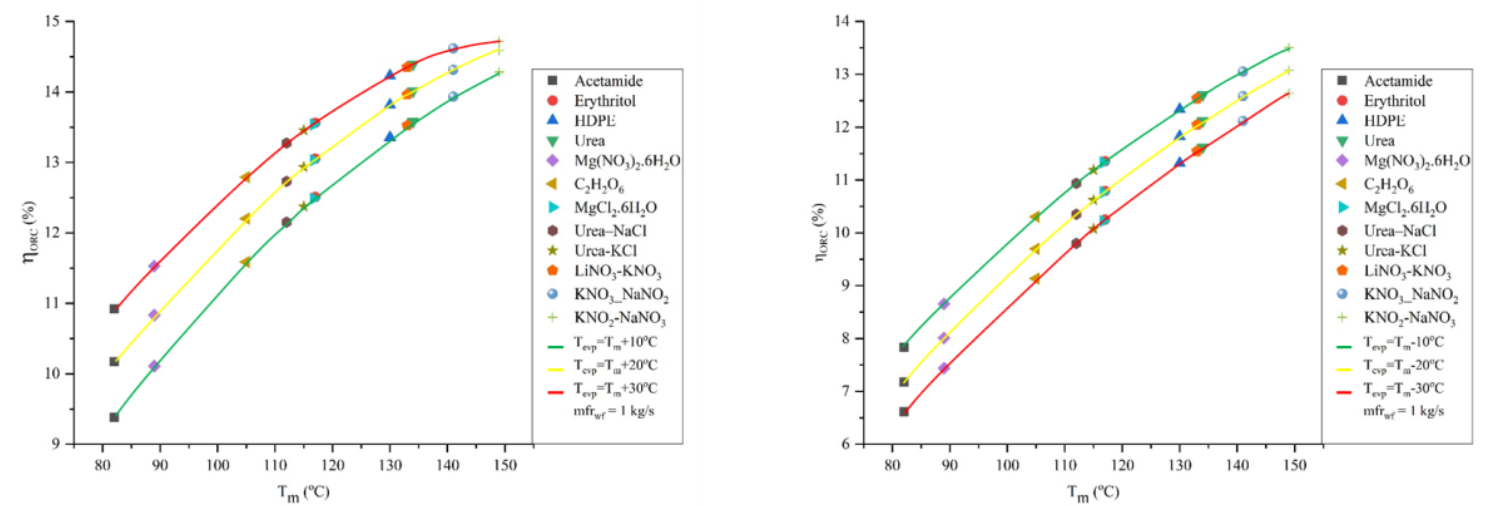

Figure 5: Influence of melting point temperature of PCM on ORC efficiency, left: Charging mode, right: discharging mode

\subsubsection{Impact of melting point temperature on collector efficiency at given evaporation temperature}

The collector efficiency is another parameter which directly impacts overall system performance. Hence, it is necessary to check the impact of PCM melting point temperature on collector efficiency. Figure 6 shows the variation in collector efficiency concerning the melting point temperature of the PCMs at a given evaporation temperature. The collector efficiency generally decreases with an increase in melting point temperature at a given evaporation temperature.

PCMs having higher melting point temperatures have shown higher decrement in the collector efficiency with an increase in evaporation temperature while PCMs having lower melting points have shown lesser decrement. For instance, $\mathrm{KNO}_{2}-\mathrm{NaNO}_{3}$ has shown a maximum decrease in collector efficiency of 
$38.21 \%$ and $4.45 \%$ with the increase in evaporation temperature while Actemide has shown a maximum increment of $1.69 \%$ and $0.5 \%$ during charging and discharging mode, respectively.

The decrement in collector efficiency is much higher during charging mode than discharging mode. For example, the decrease in the collector efficiency of $\mathrm{KNO}_{2}-\mathrm{NaNO}_{3}$ is found to be $38.21 \%$ and $4.45 \%$ during charging and discharging mode, respectively. This can happen because when evaporation temperature becomes closer to the critical point temperature of the organic fluid, decrement in collector efficiency increases. In contrast to ORC efficiency, PCMs having lower melting points have shown overall better performance by achieving higher collector efficiencies.
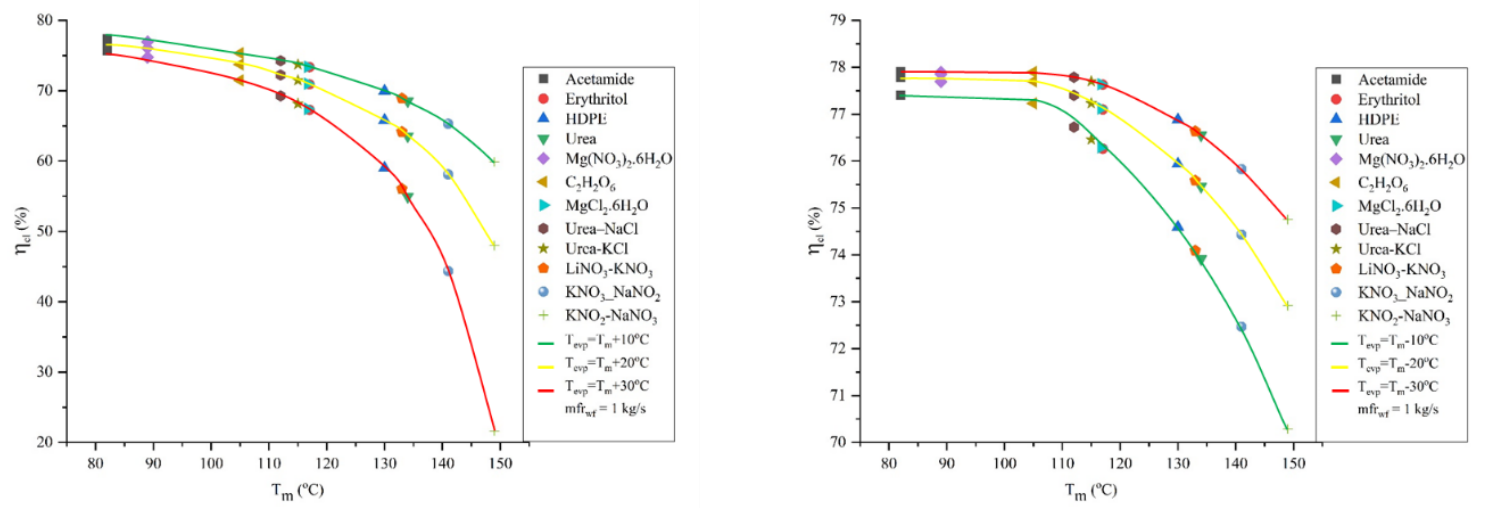

391

392

393

394

395

396

397

398

399

400

401

402

403

404

405

406

407

408

Figure 6: Influence of melting point temperature of PCM on collector efficiency, left: Charging mode, right: discharging mode

\subsubsection{Impact of melting point temperature on system efficiency at given evaporation temperature}

System efficiency is the indicator that indicates the overall performance of the system. It is a multiple of ORC and collector efficiency. Variation in collector efficiency concerning the melting point temperature of the PCMs at a given evaporation temperature is shown in Figure 7.

In contrast to both ORC and collector efficiency, the system efficiency initially increases and then starts decreasing with an increase in evaporation temperature. Therefore, it means that ORC efficiency is dominant at lower evaporation temperature while collector efficiency becomes dominant at higher evaporation temperature.

The PCMs having higher melting point temperatures have shown the least increment or even decrement in the system efficiency with an increase in evaporation temperature. However, the PCMs having lower melting points have achieved maximum increment in system efficiency with an increase in evaporation temperature. For example, $\mathrm{KNO}_{2}-\mathrm{NaNO}_{3}$ has shown a $0.05 \%$ increase in system efficiency during discharging mode while $5.35 \%$ decrease in system efficiency during charging mode with an increase in evaporation temperature. The salt hydrates PCMs have shown overall better performance by achieving higher system efficiencies. 

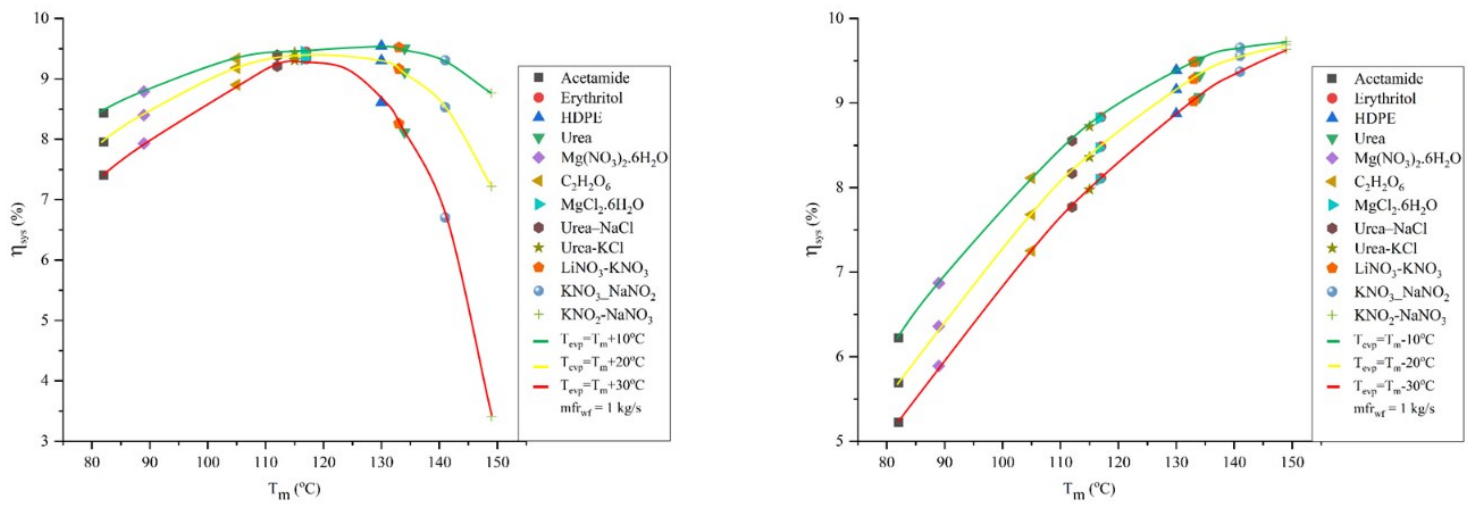

Figure 7: Influence of melting point temperature of PCM on system efficiency, left: Charging mode, right: discharging mode

\subsubsection{Impact of melting point temperature on net power output at given evaporation temperature}

Figure 8 depicts the effect of the melting point temperature of 12 different PCMs on net power output at a given evaporation temperature. Net power output is obtained by subtracting pump power from the expander power. It generally increases with an increase in evaporation temperature.

Following the trend shown by ORC efficiency, the PCMs having higher melting point temperatures have shown the least increase with the increase in evaporation temperature while PCMs of lower melting point temperatures have shown maximum increment in net power output. For example, $\mathrm{KNO}_{2}-\mathrm{NaNO}_{3}$ has achieved a minimum increment in net power output of $0.36 \mathrm{~kW}$ and $2.6 \mathrm{~kW}$ with an increase in evaporation temperature while Actemide has achieved a maximum increment of $4 \mathrm{~kW}$ and $2.72 \mathrm{~kW}$ during charging and discharging mode, respectively. Moreover, similar to the trend shown by ORC efficiency, relative increment in net power output is higher during discharging mode as compared to charging mode. For example, the net power output of $\mathrm{KNO}_{2}-\mathrm{NaNO}_{3}$ is $13.7 \mathrm{~kW}$ higher than Actemide during charging mode while its value becomes $15.18 \mathrm{~kW}$ during discharging mode. Conclusively, PCMs having higher melting points have shown overall better performance by achieving higher net power output.
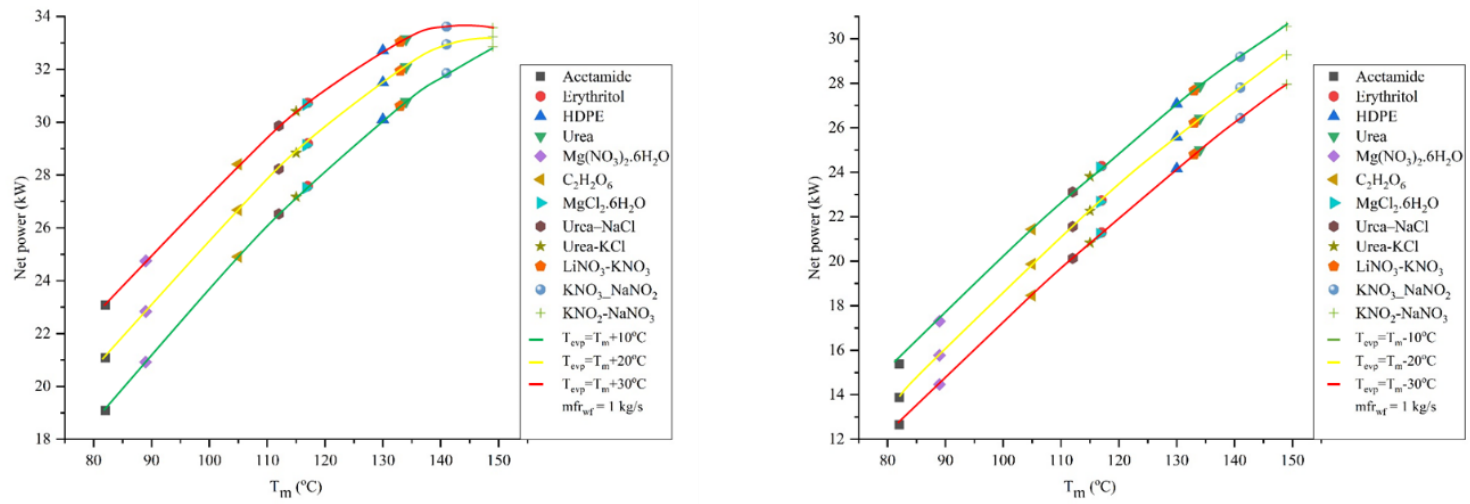

Figure 8: Influence of melting point temperature of PCM on net power output, left: Charging mode, 


\subsubsection{Impact of melting point temperature on rise and fall in organic fluid temperature at given evaporation temperature}

The organic fluid temperature increase and decrease during charging and discharging mode, respectively. It can be computed by subtracting the maximum temperature of organic fluid from minimum temperature. The drop and rise in working fluid temperature generally decrease with an increase in evaporation temperature.

The PCMs having higher melting point temperatures have shown the least decrement in the rise and fall of organic fluid temperature with an increase in evaporation temperature while PCMs having lower melting point temperatures have shown maximum decrement. For example, $\mathrm{KNO}_{2}-\mathrm{NaNO}_{3}$ has shown minimum decrement in rise and fall in organic fluid temperature of $0.12^{\circ} \mathrm{C}$ and $5.81{ }^{\circ} \mathrm{C}$ with an increase in evaporation temperature while Actemide has shown maximum decrement of $4.39^{\circ} \mathrm{C}$ and $10.89^{\circ} \mathrm{C}$ during charging and discharging mode, respectively.

The relative decrement in the rise and fall of organic fluid temperature is almost the same during charging and discharging mode. For example, the relative decrement in the rise and fall of organic fluid temperature of $\mathrm{KNO}_{2}-\mathrm{NaNO}_{3}$ and Actemide is found to be $5.6^{\circ} \mathrm{C}$ and $7.15^{\circ} \mathrm{C}$ during charging and discharging mode, respectively.

Conclusively, PCMs having lower melting points have shown overall better performance by achieving higher variation in rise and fall of organic fluid temperature.
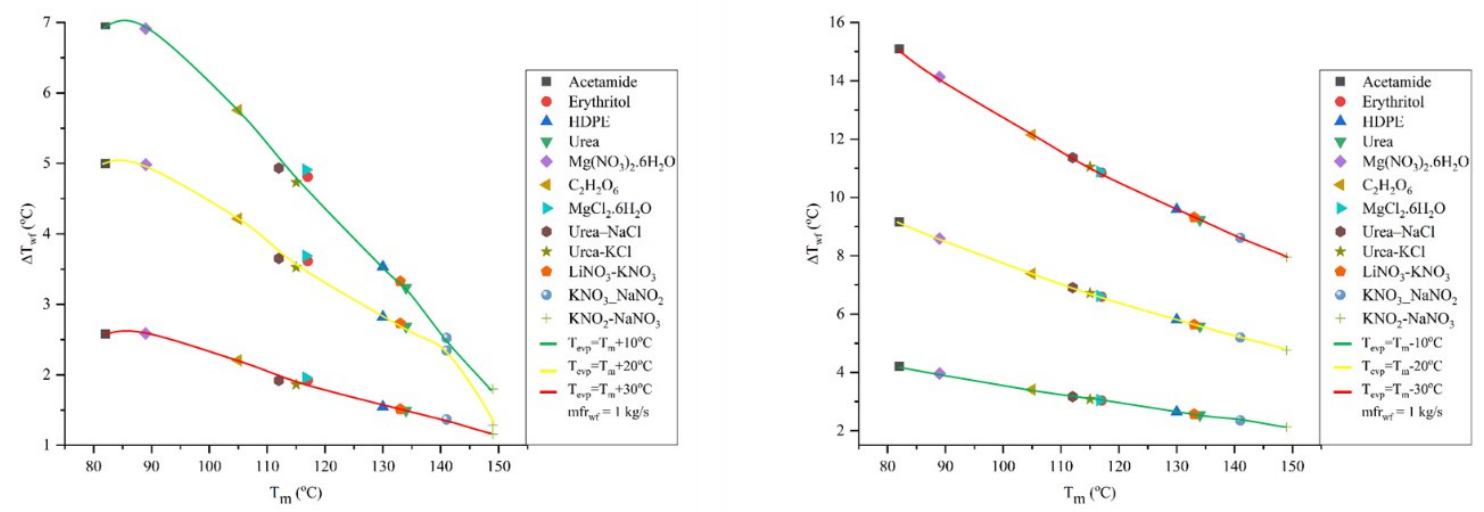

Figure 9: Influence of melting point temperature of PCM on rise and fall in organic fluid temperature, left: Charging mode, right: discharging mode

\subsubsection{Impact of melting point temperature on energy stored and released by PCMs at given evaporation temperature}

The amount of energy stored and released is one of the core criteria to evaluate the performance of PCM storage. It can be computed by multiplying the change in latent heat of PCM with a mass of PCM. It generally decreases with an increase in evaporation temperature during charging and discharging mode. In contrast to all previous indicators, energy stored and released by PCMs has not shown a regular trend. However, the PCMs having higher melting point temperatures have shown the least increment in energy stored with the increase in evaporation temperature and released while PCMs having lower melting point temperatures have shown higher increment. For example, $\mathrm{KNO}_{2}-\mathrm{NaNO}_{3}$ has shown minimum 
decrement in energy stored and released of $1.49 \mathrm{TJ}$ and $25.20 \mathrm{TJ}$ with the increase in evaporation temperature while $\mathrm{Mg}(\mathrm{NO} 3)_{2} .6 \mathrm{H}_{2} \mathrm{O}$ has shown a maximum increment of $11.45 \mathrm{TJ}$ and $25.20 \mathrm{TJ}$ during charging and discharging mode, respectively.

464 At an evaporation temperature of $10^{\circ} \mathrm{C}$ higher than melting point temperature of the PCM, The amount of energy stored by PCMs during the charging mode is lower than the energy released in discharging mode at an evaporation temperature of $10^{\circ} \mathrm{C}$ lower than melting point temperature of the PCM. When the evaporation temperature of $10^{\circ} \mathrm{C}$ higher than melting point temperature of the $\mathrm{PCM}$, the evaporation temperature of working fluid becomes closer to its critical point temperature. At this point, thermal conductivity of the working fluid decrease. Hence, it results in less heat transfer from working fluid to PCM. Therefore, amount of energy stored by PCM is decreased.

Conversely, the thermal conductivity of working fluid increase when the evaporation temperature moves away from the critical point temperature of the working fluid. Hence, it results in the higher heat transfer between PCM and working fluid. Therefore, amount of energy released by PCM is increased. higher than the amount of energy stored during the charging mode. Finally, PCMs having higher thermal conductivity and energy density have shown overall better performance because of the higher amount of energy stored and released respectively. Moreover, salt hydrates are found to best pest performers in terms of energy stored and released during charging and discharging mode, respectively.
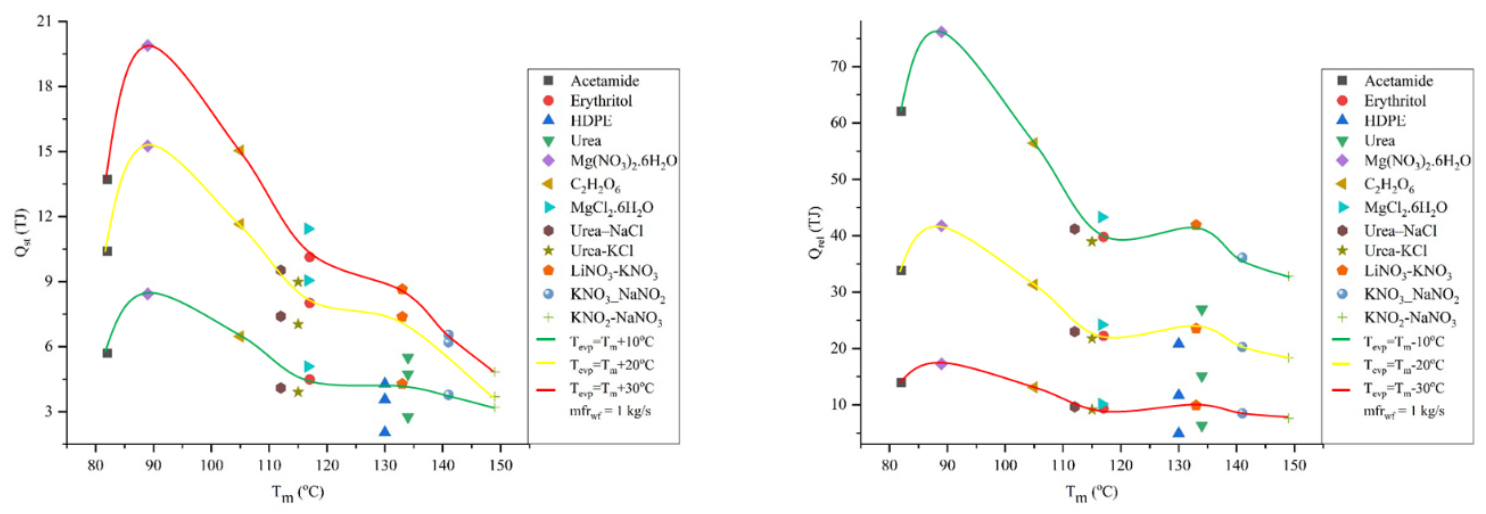

Figure 10: Influence of melting point temperature of PCM on energy stored and released by PCMs, left: Charging mode, right: discharging mode

482 Figure 10 only represent the instantaneous charging and discharging characteristics of the PCM 483 materials subjected to specific operating conditions. This does not account the dynamic response of the PCM. In order to ensure continuous operation of the PCM, it is essential to include the dynamic model and appropriate control strategy, which authors aim to include in their future work. 


\subsection{Instantaneous performance evaluation of the DVG solar ORC system at a given mass flow rate of the organic fluid}

Mass flow rate is another parameter that significantly impacts the performance of the solar ORC system. The performance of the system is evaluated at different levels of the mass flow rate of the organic fluid. The mass flow rate of organic fluid is kept $0.5,0.75$ and $1 \mathrm{~kg} / \mathrm{s}$ during charging and discharging mode, respectively. Moreover, ORC efficiency is the ratio of net power output to the input. As the mass flow rate remains the same for input and out. Hence, ORC efficiency does not vary with the variation in the mass flow rate.

\subsubsection{Impact of melting point temperature on collector efficiency at a given mass flow rate of organic fluid}

The mass flow rate of working fluid is an indicator that significantly affects the collector efficiency. Figure 11 shows the influence of the melting point of the 12 different PCMs on collector efficiency at a given mass flow rate of the organic fluid. The collector efficiency generally decreases with an increase in the melting point temperature of the PCM.

PCMs having higher melting point temperatures have shown the least increment in the collector efficiency with an increase in mass flow rate while PCMs of lower melting point have shown higher increment. For instance, $\mathrm{KNO}_{2}-\mathrm{NaNO}_{3}$ has shown the least increment in collector efficiency of $30.68 \%$ and $35.89 \%$ with an increase in mass flow rate while Actemide has shown a maximum increment of $39.45 \%$ and $39.70 \%$ during charging and discharging mode, respectively.

The trend is found to be similar in both modes of operation. However, at the very low mass flow rate, relative decrement in collector efficiency becomes very less. For example, relative decrement in the collector efficiency of Actemide and $\mathrm{KNO}_{2}-\mathrm{NaNO}_{3}$ is 3.81\% during the discharging mode. Finally, PCMs having lower melting points have shown better performance in terms of collector efficiency.
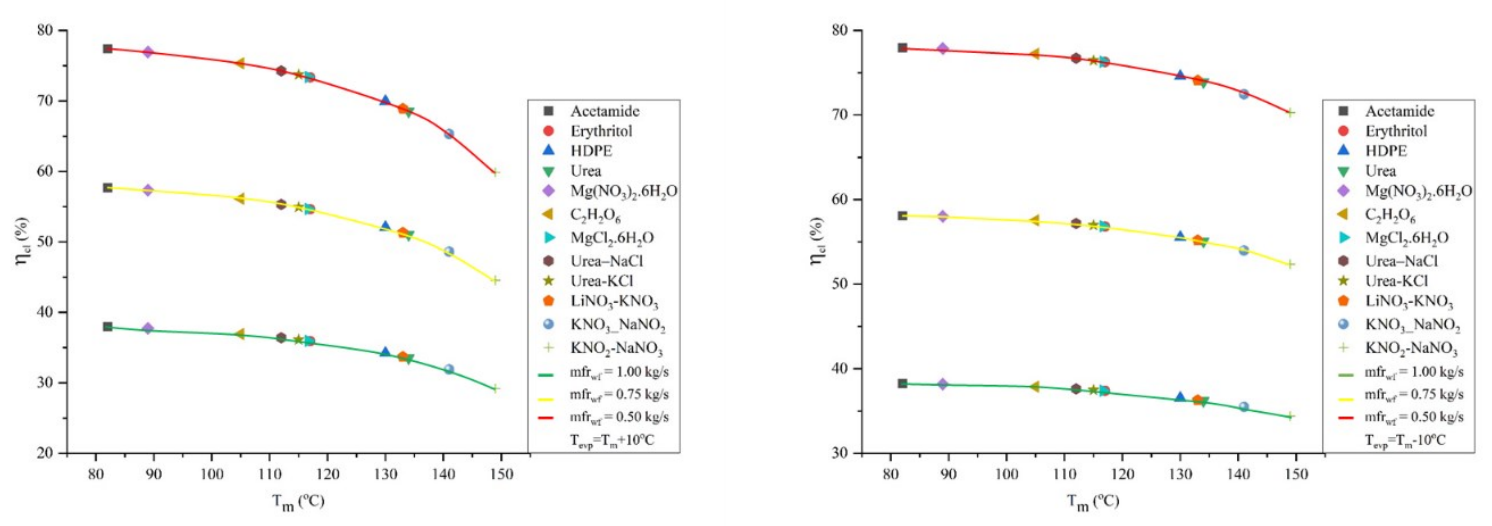


\subsubsection{Impact of melting point temperature on system efficiency at a given mass flow rate of organic fluid}

The mass flow rate of organic fluid significantly impacts the overall system efficiency of the solar organic Rankine cycle system. The impact of the melting point temperature of the PCMs on overall system efficiency at a given mass flow rate of organic fluid is shown in Figure 12. The system efficiency initially increases and then starts decreasing with an increase in melting point temperature.

The PCMs having higher melting point temperatures have shown higher decrement in the system efficiency with a decrement in mass flow rate as compared to the PCMs having lower melting point temperatures. For example, the system efficiency of $\mathrm{KNO}_{2}-\mathrm{NaNO}_{3}$ decreases by $4.38 \%$ and $4.84 \%$ during charging and discharging mode, respectively. While, the system efficiency of Acetamide decrease by $3.72 \%$ and $3.08 \%$ during charging and discharging mode, respectively.

It is found that system efficiency starts decreasing when the melting point of PCM reaches near to the critical temperature of the organic fluid. However, salt hydrates PCMs have shown better performance as compared to others because of higher system efficiency.
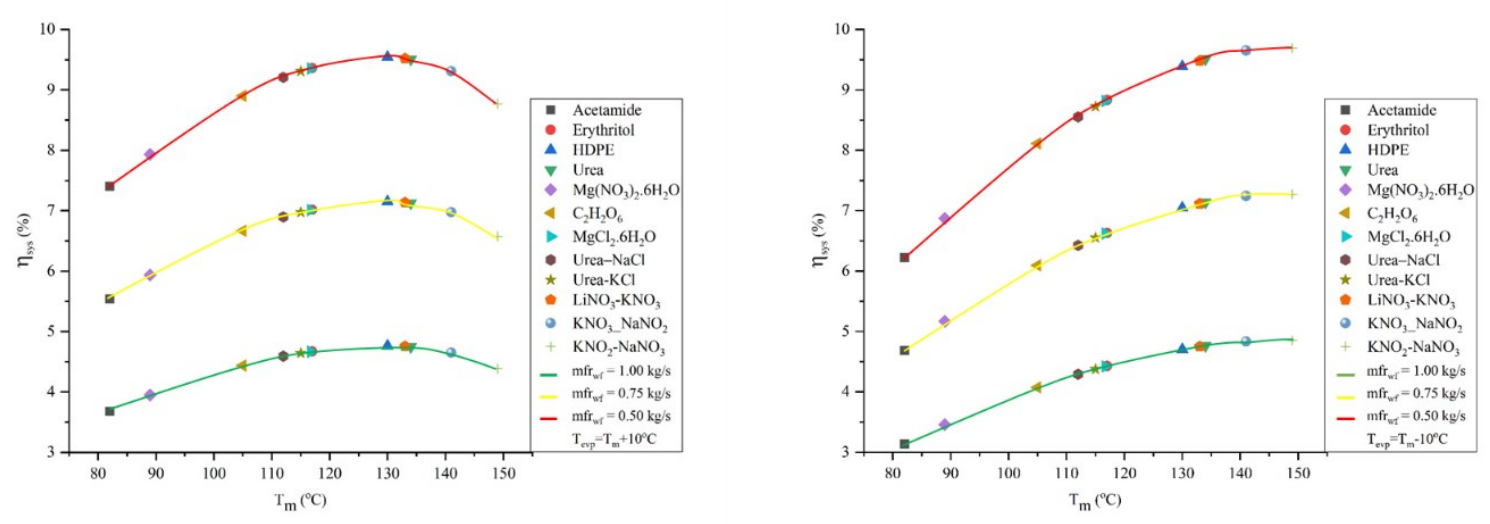

Figure 12: Influence of melting point temperature of PCMs on system efficiency, left: Charging mode, right: discharging mode

\subsubsection{Impact of melting point temperature on net power output at a given mass flow rate}

Net power output is one of the core criteria to check the performance of any power generation system. The impact of the melting point temperature of PCMs on net power output at the given mass flow rate is shown in Figure 13. The net power out is found to be a strong function of the melting point temperature of the PCM.

Power output generally increases with an increase in melting point temperature. PCMs having higher melting point temperatures have shown a maximum increase in net power output with increment in mass flow rate while PCMs of low melting point temperatures have shown minimum increment. For example, $\mathrm{KNO}_{2}-\mathrm{NaNO}_{3}$ has shown a maximum increment of $16.4 \mathrm{~kW}$ and $15.2 \mathrm{~kW}$ in net power output with an increase in mass flow rate while Actemide has shown a minimum increment of $9.4 \mathrm{~kW}$ and $7.7 \mathrm{~kW}$ during charging and charging mode, respectively. 
The relative increment in net power output of the PCMs decrease with a decrease in mass flow rate. For example, at a mass flow rate of $1 \mathrm{~kg} / \mathrm{s}$, the net power output of $\mathrm{KNO}_{2}-\mathrm{NaNO}_{3}$ is $10.4 \mathrm{~kW}$ and $11.3 \mathrm{~kW}$ higher than Actemide during charging and discharging mode respectively. While, at a mass flow rate of $0.5 \mathrm{~kg} / \mathrm{s}$, the net power output of $\mathrm{KNO}_{2}-\mathrm{NaNO}_{3}$ is $3.5 \mathrm{~kW}$ and $3.7 \mathrm{~kW}$ higher than Actemide during charging and discharging mode respectively. PCMs having higher melting points have shown overall better performance due to the higher net power output.
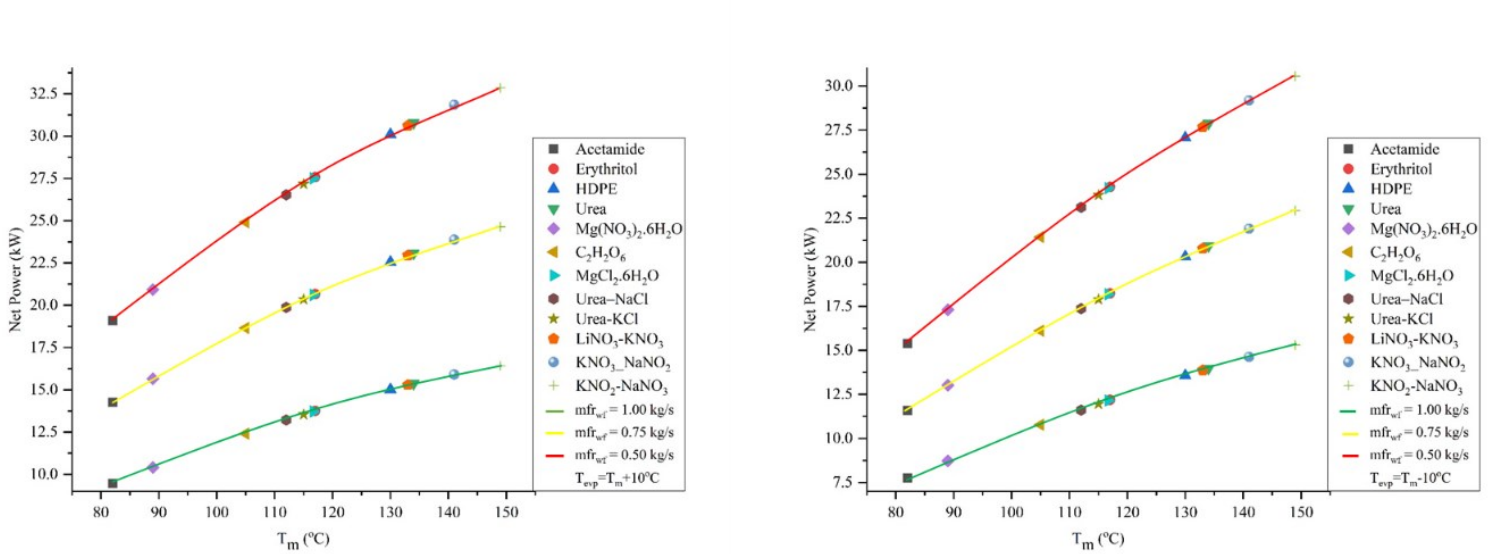

Figure 13: Influence of melting point temperature of PCMs on net power output, left: Charging mode, right: discharging mode

\subsubsection{Impact of melting point temperature on rise and fall in organic fluid temperature at a given mass flow rate}

The rise and fall in organic fluid temperature while passing through a PCM storage tank is an important parameter to measure the performance of a heat storage tank which further impacts overall system performance. The impact of melting point temperature of PCMs on rise and fall in organic fluid temperature at a given mass flow rate is shown in Figure 14. The rise and fall in organic fluid temperature generally decrease with an increase in the melting point temperature of the PCM.

PCMs having higher melting point temperatures have shown less decrement in the rise and fall of organic fluid temperature with an increase in mass flow rate while PCMs of low melting point have shown higher decrement. For example, $\mathrm{KNO}_{2}-\mathrm{NaNO}_{3}$ has shown a minimum decrement of $0.23{ }^{\circ} \mathrm{C}$ and $0.3^{\circ} \mathrm{C}$ with an increase in mass flow rate while Actemide has shown a maximum decrement of $0.54^{\circ} \mathrm{C}$ and $0.49^{\circ} \mathrm{C}$ during charging and discharging mode, respectively.

At a given mass flow rate, the relative decrement in rising and fall of organic fluid temperature is higher during charging as compared to discharging mode. For example, at a mass flow rate of $1 \mathrm{~kg} / \mathrm{s}$, the relative decrement in the rise and fall of organic fluid temperature of $\mathrm{KNO}_{2}-\mathrm{NaNO}_{3}$ and Actemide is found to be $1.4^{\circ} \mathrm{C}$ and $2.07^{\circ} \mathrm{C}$ during charging and discharging mode, respectively.

The PCMs having lower melting point temperatures have shown overall better performance due to higher values of rise and fall in organic fluid temperature during charging and discharging mode, respectively. 

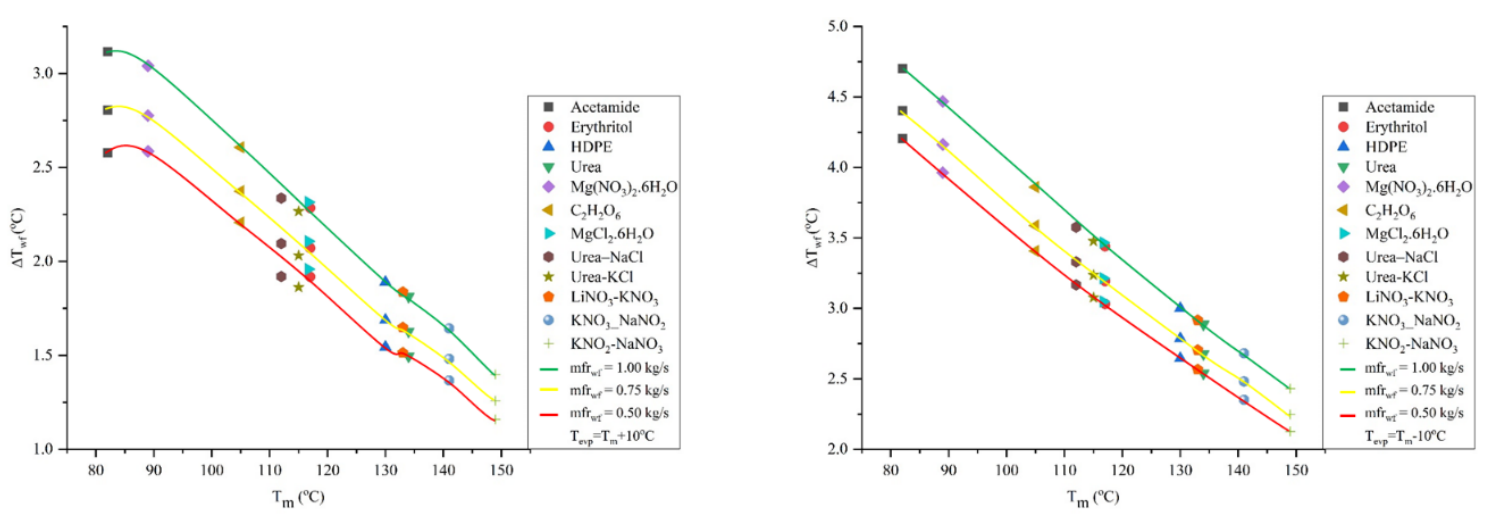

Figure 14: Influence of melting point temperature of PCMs on rise and fall in organic fluid temperature, left: Charging mode, right: discharging mode

\subsubsection{Impact of melting point temperature on energy stored and released by PCMs at a given mass flow rate}

The amount of energy stored and released are the major criteria to evaluate the performance of a heat storage tank. Therefore, Figure 15 depicts the impact of the melting point temperature of PCMs on the amount of energy stored and released during charging and discharging mode at a given mass flow rate. In contrast to all other parameters, there is no specific trend shown by energy stored and released by the PCMs employed in the system. However, the amount of energy stored and released generally decreases with an increase in melting point temperature.

The PCM having higher melting point temperature has shown the least decrement in the amount of energy stored and released with a decrease in mass flow rate as compared to PCMs having lower melting point temperature. For example, $\mathrm{KNO}_{2}-\mathrm{NaNO}_{3}$ has shown minimum decrement in energy stored and released of $0.82 \mathrm{TJ}$ and $2.6 \mathrm{TJ}$ with a decrease in mass flow rate while $\mathrm{Mg}\left(\mathrm{NO}_{3}\right)_{2} .6 \mathrm{H}_{2} \mathrm{O}$ has shown maximum decrement of $2.37 \mathrm{TJ}$ and $6.28 \mathrm{TJ}$ during charging and discharging mode, respectively.

At a given mass flow rate, the amount of energy absorbed by PCMs during charging mode is found to be less than the amount of energy released during discharging mode. For example, at a mass flow rate of $1 \mathrm{~kg} / \mathrm{s}$, the amount of energy absorbed by $\mathrm{KNO}_{2}-\mathrm{NaNO}_{3}$ during the charging mode is $1.8 \mathrm{TJ}$ less than the amount of energy released during discharging mode.

Finally, Salt hydrates PCMs have shown overall better performance because of the higher amount of energy stored and released during charging and discharging mode, respectively. 

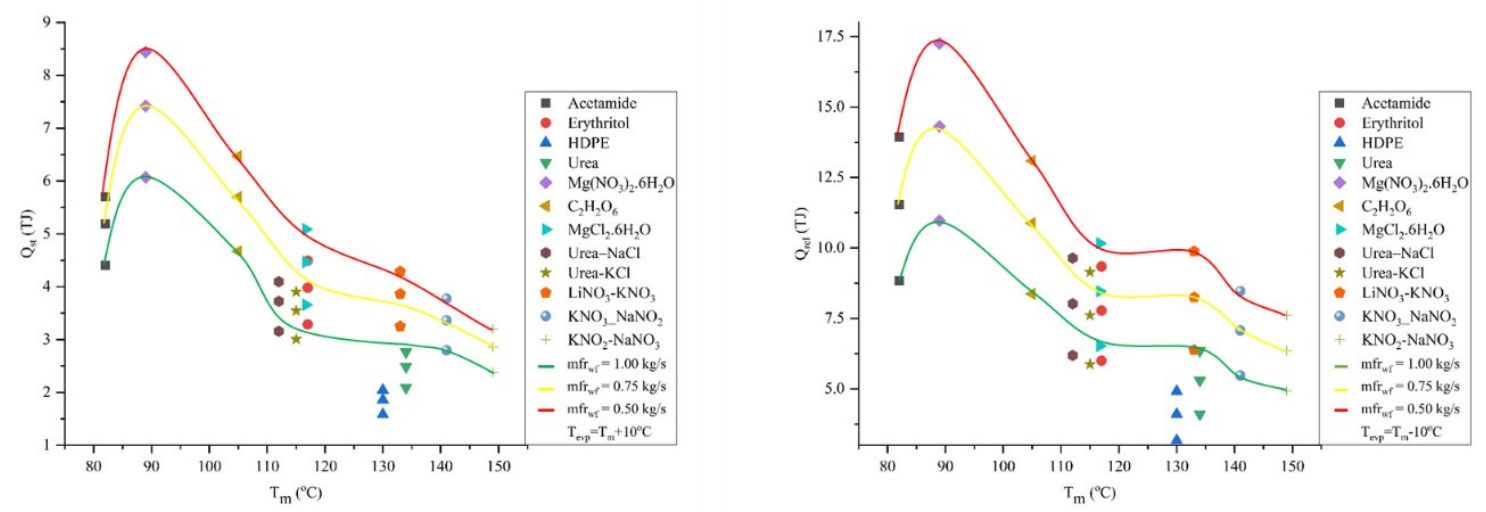

Figure 15: Influence of melting point temperature of PCMs on energy stored and released by PCMs, left: Charging mode, right: discharging mode

\section{Conclusions}

A direct vapor generation solar ORC system is considered in this study. An array of evacuated flat plate collectors is used to transmit heat to the system. A PCM storage tank is coupled with the system for the stability of power generation. Moreover, 12 different phase change storage materials are employed to evaluate the overall performance of the system. The whole system is modeled in MATLAB program to simulate charging and discharging mode. The simulation period is kept 24 hour during both modes for each PCM employed in the system.

The impact of evaporation temperature and mass flow rate on ORC, collector and overall system efficiency is analyzed during charging and discharging mode. At given operating conditions, the PCMs having a higher melting point temperature have shown higher ORC efficiency. Conversely, the collector efficiency is higher for the PCMs having low melting point temperature. However, the salt hydrates PCMs have shown better performance in terms of overall system efficiency. For example, at given evaporation temperature and mass flow rate, $\mathrm{KNO}_{2}-\mathrm{NaNO}_{3}$ and Actemide have achieved maximum ORC and collector efficiency, respectively during both modes of operation. However, $\mathrm{MgCl}_{2} \cdot 6 \mathrm{H}_{2} \mathrm{O}$ has shown the highest overall system efficiency at given evaporation temperature and mass flow rate during both modes of the operation. Moreover, ORC efficiency is found to be in the range of $9 \%$ to $15 \%$, the collector efficiency lies between $23 \%$ to $76 \%$ and overall system efficiency remains in $3 \%$ to $9 \%$ during both modes of operation.

The effect of evaporation temperature and mass flow rate on net power output, variation in organic fluid temperature and amount of energy stored and released during charging and discharging mode is also evaluated. At given evaporation temperature and mass flow rate, the PCMs having a higher melting point temperature have shown higher net power output. Conversely, the rise and fall in organic fluid temperatures are higher for the PCMs having low melting point temperature. However, the salt hydrates PCMs have shown better performance in terms of energy stored and released during charging and discharging mode. For example, $\mathrm{KNO}_{2}-\mathrm{NaNO}_{3}$ and Actemide have shown maximum net power output 
and variation in organic fluid temperature, respectively, at given evaporation temperature and mass flow rate. Furthermore, net power output is found to be in the range of $9 \mathrm{~kW}$ to $34 \mathrm{~kW}$, the rise and fall in organic fluid temperature lies between $1.5^{\circ} \mathrm{C}$ to $16^{\circ} \mathrm{C}$ and energy stored and released remains in $0.52 \mathrm{TJ}$ to $75 \mathrm{TJ}$ during both modes of operation.

Finally, salt hydrates PCMs have shown better performance in terms of overall system efficiency and the amount of energy stored and released. However, $\mathrm{Mg}(\mathrm{NO} 3) 2.6 \mathrm{H} 2 \mathrm{O}$ is found to be most suitable among the selected PCM because of its all-round better performance.

The dynamic aspect and control of the PCM based of the ORC system has not been considered in present study. In order to ensure the continuous operation of the PCM based ORC system, it is essential to develop appropriate control strategy and develop the dynamic model that can provide a detail insight to the performance of the PCM over the time (at least weekly or monthly simulation). The evaluation of the annual performance of the system would lead to a more robust performance prediction and, consequently, to an iterative re-design of the system components in order to define the optimal design for a given reference geographic position.

\section{Acknowledgment}

This research work has been supported by the National Natural Science Foundation of China (51806081), the Natural Science Foundation of Jiangsu Province (BK20180882), the China Postdoctoral Science Foundation (2018M632241) and the Open Foundation Program of Key Laboratory of Efficient Utilization of Low and Medium Grade Energy (Tianjin University), the Ministry of Education of China (201806-402).

\section{Nomenclature}

\section{Symbols}

$$
w_{t}
$$$$
w_{p}
$$

$h_{t, i}$

$$
h_{t, o}
$$$$
h_{t, o s}
$$

$m$

$\varepsilon_{t}$

$$
\varepsilon_{p}
$$$$
\varepsilon_{g}
$$

$$
\eta_{O R C}
$$

A

$G$
Work done by expander, $\mathrm{W}$

Work done by pump, W

Enthalpy at expander inlet, $\mathrm{kJ} / \mathrm{kg}$

Enthalpy at expander outlet, $\mathrm{kJ} / \mathrm{kg}$

Enthalpy of expander at ideal thermodynamic process, $\mathrm{kJ} / \mathrm{kg}$

Working fluid mass flow rate, $\mathrm{kg} / \mathrm{s}$

Efficiency of expander, \%

Efficiency of pump, \%

Efficiency of generator, \%

Efficiency of organic Rankine cycle, \%

Area, $\mathrm{m}^{2}$

Irradiation, $\mathrm{W} / \mathrm{m}^{2}$ 


\begin{tabular}{|c|c|c|}
\hline 656 & $\beta$ & Angle \\
\hline 657 & Q & Amount of energy, $\mathrm{J}$ \\
\hline 658 & $T$ & Temperature of collector, ${ }^{\circ} \mathrm{C}$ \\
\hline 659 & $\mathrm{~T}_{\mathrm{c}}$ & Critical temperature, ${ }^{\circ} \mathrm{C}$ \\
\hline 660 & $T_{a}$ & Ambient temperature, ${ }^{\circ} \mathrm{C}$ \\
\hline 661 & $c_{p}$ & Specific heat, $J /(\mathrm{kg} \cdot K)$ \\
\hline 662 & $T_{f, o}$ & Temperature of fluid at collector outlet, ${ }^{\circ} \mathrm{C}$ \\
\hline 663 & $T_{f, i}$ & Temperature of fluid at collector inlet, ${ }^{\circ} \mathrm{C}$ \\
\hline 664 & $S_{l}$ & Surface area of collector in liquid phase, $\mathrm{m}^{2}$ \\
\hline 665 & $S_{b}$ & Surface area of collector in binary phase, $\mathrm{m}^{2}$ \\
\hline 666 & $\eta_{c, l}$ & Efficiency of collector in liquid phase, $\%$ \\
\hline 667 & $\eta_{c, v}$ & Efficiency of collector in binary phase, $\%$ \\
\hline 668 & $h_{l, o}$ & Enthalpy at liquid phase outlet, $\mathrm{kJ} / \mathrm{kg}$ \\
\hline 669 & $h_{l, i}$ & Enthalpy at liquid phase inlet, $\mathrm{kJ} / \mathrm{kg}$ \\
\hline 670 & $h_{b, o}$ & Enthalpy at binary phase outlet, $\mathrm{kJ} / \mathrm{kg}$ \\
\hline 671 & $h_{b, i}$ & Enthalpy at binary phase inlet, $\mathrm{kJ} / \mathrm{kg}$ \\
\hline 672 & $m_{f}$ & Working fluid mass flow rate, $\mathrm{kg} / \mathrm{s}$ \\
\hline 673 & $\eta_{c}$ & Efficiency of collector system, $\%$ \\
\hline 674 & $\eta_{o}$ & Maximum Efficiency, \% \\
\hline 675 & $\eta_{s y s}$ & System thermal efficiency, $\%$ \\
\hline 676 & rho & Density, $\mathrm{g} / \mathrm{m}^{3}$ \\
\hline 677 & Abbreviations & \\
\hline 678 & GWP & Global Warming Potential \\
\hline 679 & ODP & Ozone Depletion Potential \\
\hline 680 & ORC & Organic Rankine Cycle \\
\hline 681 & DVG & Direct vapor generation \\
\hline 682 & FPC & Flat plate collector \\
\hline 683 & $\mathrm{CPC}$ & Compound parabolic concentrator \\
\hline 684 & ETC & Evacuated tube collector \\
\hline 685 & PTC & Parabolic trough concentrator \\
\hline 686 & $\mathrm{CHP}$ & Combined heat and power \\
\hline 687 & HTF & Heat transfer fluid \\
\hline 688 & DSG & direct steam generation \\
\hline
\end{tabular}




\begin{tabular}{|c|c|c|}
\hline 689 & CSP & Concentrated solar power \\
\hline 690 & PCM & Phase change material \\
\hline 691 & $\mathrm{G}$ & Generator \\
\hline 692 & $\mathrm{P}$ & Pump \\
\hline 693 & Subscript & \\
\hline 694 & ORC & Organic Rankine Cycle \\
\hline 695 & $O p t$ & Optimum \\
\hline 696 & $\max$ & maximum \\
\hline 697 & Sys & System \\
\hline 698 & $c$ & critical \\
\hline 699 & $i$ & inlet \\
\hline 700 & $o$ & outlet \\
\hline 701 & 0 & Reference state \\
\hline 702 & $\mathrm{~m}$ & Melting point \\
\hline 703 & $e v p$ & evaporation \\
\hline 704 & $\mathrm{amb}$ & ambient \\
\hline 705 & st & stored \\
\hline 706 & rel & released \\
\hline 707 & & \\
\hline 708 & & \\
\hline 709 & & \\
\hline 710 & & \\
\hline 711 & & \\
\hline 712 & & \\
\hline 713 & & \\
\hline 714 & & \\
\hline 715 & & \\
\hline 716 & & \\
\hline 717 & & \\
\hline 718 & & \\
\hline 719 & & \\
\hline 720 & & \\
\hline 721 & & \\
\hline
\end{tabular}




\section{References}

727

[1] Peng S, Hong H, Jin H, Wang Z. An integrated solar thermal power system using intercooled gas turbine and Kalina cycle. Energy 2012;44:732-40.

[2] Yogi Goswami D. Solar thermal power technology: present status and ideas for the future. Energy Sources 1998;20:137-45.

[3] Zamfirescu C, Dincer I. Thermodynamic analysis of a novel ammonia-water trilateral Rankine cycle. Thermochim Acta 2008;477:7-15.

[4] Li J, Alvi JZ, Pei G, Su Y, Li P, Gao G, et al. Modelling of organic Rankine cycle efficiency with respect to the equivalent hot side temperature. Energy 2016;115:668-83. doi:10.1016/j.energy.2016.09.049.

[5] Freeman J, Guarracino I, Kalogirou SA, Markides CN. A small-scale solar organic Rankine cycle combined heat and power system with integrated thermal energy storage. Appl Therm Eng 2017;127:1543-54. doi:10.1016/j.applthermaleng.2017.07.163.

[6] Drescher U, Br??ggemann D. Fluid selection for the Organic Rankine Cycle (ORC) in biomass power and heat plants. Appl Therm Eng 2007;27:223-8. doi:10.1016/j.applthermaleng.2006.04.024.

[7] Alvi JZ, Feng Y, Wang Q, Imran M. Modelling, simulation and comparison of phase change material storage. Appl Therm Eng 2019:114780. doi:10.1016/j.applthermaleng.2019.114780.

[8] Alvi JZ, Imran M, Pei G, Li J, Gao G, Alvi J. Thermodynamic comparison and dynamic simulation of direct and indirect solar organic Rankine cycle systems with PCM storage. Energy Procedia 2017;129:716-23. doi:10.1016/j.egypro.2017.09.103.

[9] Wang XD, Zhao L, Wang JL. Experimental investigation on the low-temperature solar Rankine cycle system using R245fa. Energy Convers Manag 2011;52:946-52. doi:10.1016/j.enconman.2010.08.022.

[10] Wang JL, Zhao L, Wang XD. An experimental study on the recuperative low temperature solar Rankine cycle using R245fa. Appl Energy 2012;94:34-40. doi:10.1016/j.apenergy.2012.01.019.

[11] Li J, Alvi JZ, Pei G, Ji J, Li P, Fu H. Effect of working fluids on the performance of a novel direct vapor generation solar organic Rankine cycle system. Appl Therm Eng 2016;98:786-97. doi:10.1016/j.applthermaleng.2015.12.146.

[12] Bu XB, Li HS, Wang LB. Performance analysis and working fluids selection of solar powered organic Rankine-vapor compression ice maker. Sol Energy 2013;95:271-8. doi:10.1016/j.solener.2013.06.024.

[13] Wang XD, Zhao L, Wang JL, Zhang WZ, Zhao XZ, Wu W. Performance evaluation of a lowtemperature solar Rankine cycle system utilizing R245fa. Sol Energy 2010;84:353-64. doi:10.1016/j.solener.2009.11.004.

[14] Gang P, Jing L, Jie J. Design and analysis of a novel low-temperature solar thermal electric system with two-stage collectors and heat storage units. Renew Energy 2011. 
doi:10.1016/j.renene.2011.02.008.

[15] Li J, Li P, Pei G, Alvi JZ, Ji J. Analysis of a novel solar electricity generation system using cascade Rankine cycle and steam screw expander. Appl Energy 2016;165:627-38. doi:10.1016/j.apenergy.2015.12.087.

[16] Gang P, Guiqiang L, Xi Z, Jie J, Yuehong S. Experimental study and exergetic analysis of a CPC-type solar water heater system using higher-temperature circulation in winter. Sol Energy 2012;86:1280-6.

[17] Li X, Dai YJ, Li Y, Wang RZ. Comparative study on two novel intermediate temperature CPC solar collectors with the U-shape evacuated tubular absorber. Sol Energy 2013;93:220-34.

[18] Calise F, D'Accadia MD, Vicidomini M, Scarpellino M. Design and simulation of a prototype of a small-scale solar CHP system based on evacuated flat-plate solar collectors and Organic Rankine Cycle. Energy Convers Manag 2015;90:347-63. doi:10.1016/j.enconman.2014.11.014.

[19] Li J, Li P, Pei G, Ji J, Alvi JZ, Xia L. a Novel Hybrid Solar Power Generation System Using aSi Photovoltaic / Thermal Collectors and Organic Rankine Cycle. Proc 3rd Int Semin ORC Power Syst 2015:1-10.

[20] Tian Y, Zhao CY. A review of solar collectors and thermal energy storage in solar thermal applications. Appl Energy 2013;104:538-53. doi:10.1016/J.APENERGY.2012.11.051.

[21] Sharma A, Tyagi VV, Chen CR, Buddhi D. Review on thermal energy storage with phase change materials and applications. Renew Sustain Energy Rev 2009;13:318-45. doi:10.1016/J.RSER.2007.10.005.

[22] Hasnain SM. Review on sustainable thermal energy storage technologies, Part I: heat storage materials and techniques. Energy Convers Manag 1998;39:1127-38. doi:10.1016/S01968904(98)00025-9.

[23] Manfrida G, Secchi R, Stańczyk K. Modelling and simulation of phase change material latent heat storages applied to a solar-powered Organic Rankine Cycle. Appl Energy 2016;179:37888. doi:10.1016/j.apenergy.2016.06.135.

[24] Waqas A, Ji J, Xu L, Ali M, Zeashan, Alvi JZ. Thermal and electrical management of photovoltaic panels using phase change materials - A review. Renew Sustain Energy Rev 2018;92:254-71. doi:10.1016/j.rser.2018.04.091.

[25] Zhou D, Zhao CY, Tian Y. Review on thermal energy storage with phase change materials (PCMs) in building applications. Appl Energy 2012;92:593-605. doi:10.1016/J.APENERGY.2011.08.025.

[26] Agyenim F, Hewitt N, Eames P, Smyth M. A review of materials, heat transfer and phase change problem formulation for latent heat thermal energy storage systems (LHTESS). Renew Sustain Energy Rev 2010;14:615-28. doi:10.1016/J.RSER.2009.10.015.

[27] Grange B, Dalet C, Falcoz Q, Ferrière A, Flamant G. Impact of thermal energy storage integration on the performance of a hybrid solar gas-turbine power plant. Appl Therm Eng 2016;105:266-75. doi:10.1016/j.applthermaleng.2016.05.175.

[28] Abbasi HR, Pourrahmani H. Multi-objective optimization and exergoeconomic analysis of a continuous solar-driven system with PCM for power, cooling and freshwater production. Energy Convers Manag 2020;211:112761. doi:10.1016/j.enconman.2020.112761.

[29] Abbasi HR, Pourrahmani H, Yavarinasab A, Emadi MA, Hoorfar M. Exergoeconomic optimization of a solar driven system with reverse osmosis desalination unit and phase change material thermal energy storages. Energy Convers Manag 2019;199:112042. 
doi:10.1016/j.enconman.2019.112042.

[30] Liu M, Steven Tay NH, Bell S, Belusko M, Jacob R, Will G, et al. Review on concentrating solar power plants and new developments in high temperature thermal energy storage technologies. Renew Sustain Energy Rev 2016;53:1411-32. doi:10.1016/j.rser.2015.09.026.

[31] Pei G, Li J, Ji J. Analysis of low temperature solar thermal electric generation using regenerative Organic Rankine Cycle. Appl Therm Eng 2010;30:998-1004. doi:10.1016/j.applthermaleng.2010.01.011.

[32] Lakhani S, Raul A, Saha SK. Dynamic modelling of ORC-based solar thermal power plant integrated with multitube shell and tube latent heat thermal storage system. Appl Therm Eng 2017;123:458-70. doi:10.1016/j.applthermaleng.2017.05.115.

[33] Iasiello M, Braimakis K, Andreozzi A, Karellas S. Thermal analysis of a Phase Change Material for a Solar Organic Rankine Cycle. J Phys Conf Ser 2017;923:012042. doi:10.1088/1742-6596/923/1/012042.

[34] Costa S-C, Mahkamov K, Kenisarin M, Lynn K, Halimic E, Mullen D. Solar Salt Latent Heat Thermal Storage for a Small Solar Organic Rankine Cycle Plant. ASME 2018 12th Int. Conf. Energy Sustain. Collocated with ASME 2018 Power Conf. ASME 2018 Nucl. Forum, p. V001T08A002, ASME Pap. No. ES2018-7326, 2018.

[35] Costa S-C, Mahkamov K, Kenisarin M, Ismail M, Lynn K, Halimic E, et al. Solar Salt Latent Heat Thermal Storage for a Small Solar Organic Rankine Cycle Plant. J Energy Resour Technol 2020;142.

[36] Meteonorm. Global Solar Radiation Database - METEONORM 2015.

[37] Hajabdollahi H, Ganjehkaviri A, Mohd Jaafar MN. Thermo-economic optimization of RSORC (regenerative solar organic Rankine cycle) considering hourly analysis. Energy 2015;87:361-8. doi:10.1016/j.energy.2015.04.113.

[38] TVP Solar Datasheet, HT-Power Product n.d. https://www.tvpsolar.com/attach/MT-Power Datasheet (v4 SK).pdf (accessed June 7, 2020).

[39] Voller VR, Cross M, Markatos NC. An enthalpy method for convection/diffusion phase change. Int J Numer Methods Eng 1987;24:271-84. doi:10.1002/nme.1620240119.

[40] Günther E, Hiebler S, Mehling H, Redlich R. Enthalpy of Phase Change Materials as a Function of Temperature : Required Accuracy and Suitable Measurement Methods. Int J Thermophys 2009;30:1257-69. doi:10.1007/s10765-009-0641-z.

[41] Waqas A, Ji J. Thermal management of conventional PV panel using PCM with movable shutters - A numerical study. Sol Energy 2017;158:797-807. doi:10.1016/j.solener.2017.10.050.

[42] Nallusamy N, Sampath S, Velraj R. Experimental investigation on a combined sensible and latent heat storage system integrated with constant/varying (solar) heat sources. Renew Energy 2007;32:1206-27.

[43] Mosaffa AH, Ferreira CAI, Talati F, Rosen MA. Thermal performance of a multiple PCM thermal storage unit for free cooling. Energy Convers Manag 2013;67:1-7. doi:10.1016/j.enconman.2012.10.018.

[44] Usman M, Imran M, Yang Y, Lee DH, Park B-S. Thermo-economic comparison of air-cooled and cooling tower based Organic Rankine Cycle (ORC) with R245fa and R1233zde as candidate working fluids for different geographical climate conditions. Energy 2017;123:35366. doi:https://doi.org/10.1016/j.energy.2017.01.134. 
